SAD / JSR

Sosyoloji Araştırmaları Dergisi / Journal of Sociological Research

Cilt / Volume 24 Sayı / Number 3 (Ekim / October 2021) : (135-184)
Araştırma Makalesi / Research Article

Geliș Tarihi / Submited: 20.07.2021

Kabul Tarihi / Accepted: 30.09.2021

\title{
SOCIAL CAPITAL REVISITED: CONCEPT AND MEASUREMENT
}

\author{
Hande HACIMAHMUTOĞLU ${ }^{1}$ \\ İlknur YÜKSEL-KAPTANOĞLU²
}

\begin{abstract}
The concept of social capital implies to the benefit of social relations for individuals and community.

The complicated structure of social capital led the theoreticians to see it from varying aspects and forms, and the researchers to measure it in many different ways. Examining the existing studies in the literature, it is understood that while measuring social capital, a definition of the aspects and the level of analysis appropriate to the social capital theory that is employed is necessary. In this context, the researcher has to decide the level of the research and the theory that lays behind the necessary assumptions for the study. It is essential to consider both structural and cognitive aspects of social capital for its measurement. Regarding the data sources that are utilized in the existing empirical studies, time-use surveys provide a broad scale information that enable to investigate the structural aspect of social capital-which might be observed via objective methods, but it is limited for the cognitive aspect- which might be better observed via subjective methods. Hence, concertedly utilised quantitative and qualitative methods would provide the broadest and convenient data and information about social capital.
\end{abstract}

Keywords: Social Capital, Social Relations, Social Ties, Time-Use Survey, Quantitative Analysis, Turkey.

\footnotetext{
${ }^{1}$ Doktora öğrencisi, Hacettepe Üniversitesi Nüfus Etütleri Enstitüsü, ORCID: 0000-0001-9533-1811

2 Doç., Dr., Hacettepe Üniversitesi Nüfus Etütleri Enstitüsü, ORCID: 0000-0001-5969-1238 


\section{SOSYAL SERMAYENIN YENİDEN GÖZDEN GEÇİRILMESİ: KAVRAM VE ÖLÇÜMÜ}

\section{ÖZ}

Sosyal sermaye kavramı sosyal ilişkilerin bireyler ve toplum açısından faydasına işaret etmektedir. Sosyal sermayenin karmaşık yapısı teorisyenlerin bu kavramı farklı yönlerden ve farklı şekillerde görmelerine ve araştırmacıların sosyal sermayeyi farklı yollardan ölçmelerine neden olmaktadır. Yazında mevcut çalışmalar incelendiğinde, sosyal sermayenin analiz düzeyinin ve boyutlarının benimsenen sosyal sermaye teorisine uygun olacak bir şekilde tanımlanmasının gerektiği anlaşılmaktadır. Bu kapsamda, araştırmacının çalışmanın düzeyine ve çalışmada kullandığı varsayımların arkasında yatan teoriye karar vermesi gerekmektedir. Sosyal sermayenin ölçümünde hem yapısal hem de bilişsel boyutlarının dikkate alınması önemlidir. Mevcut ampirik çalışmalarda kullanılan veri kaynakları göz önünde bulundurulduğunda, zaman kullanımı araştırmalarının, sosyal sermayenin yapısal boyutunu inceleme açısından çok geniş kapsamlı veri sunduğu görülmektedir. Ancak bu anketlerin sağladığı veri, sosyal sermayenin öznel yöntemlerle daha iyi gözlenebilen bilişsel boyutu açısından kısıtlıdır. Dolayısıyla uyumlu bir şekilde kullanılan niceliksel ve niteliksel yöntemler sosyal sermayeye ilişkin en geniş ve uygun veriyi ve bilgiyi sağlayacağı düşünülmektedir.

Anahtar Kelimeler: Sosyal Sermaye, Sosyal İlişkiler, Sosyal Bağlar, Zaman Kullanımı Araştırması, Nicel Analiz, Türkiye. 


\section{INTRODUCTION}

In the simplest way, the social capital concept can be defined as the relations among individuals. In a more complex way, it is the effects of these relations regarding the quality of information that is provided through these relations to facilitate actions of individuals. Nevertheless, in literature, it has been referred as a blurred concept that is difficult to be specified via crystal-clear definitions.

The concept of social capital has been discussed in many disciplines and the efforts to measure has enriched the discussions. Being a controversial subject among the theoreticians, social capital is measured by different means depending on the inclination of the researcher towards how to define social capital, within theory kind (e.g. sociological, developmental; collective, private; relational, owned etc.); having which forms and aspects (bond, bridge, link; structural, cognitive) and standing level (individual, societal, national; micro, meso, macro).

In order to study social capital concept, one needs to decide the level of the research and the theory that lays behind the necessary assumptions for the study. Social capital concept can be examined by looking through individual (Coleman, 1988; Bourdieu, 1986), community or national level (Putnam, 2000), assuming social capital being a private (Bourdieu, 1986) or a collective good (Coleman, 1988; Putnam, 2000), describing its forms as bonding, bridging and/or linking, defining it as networks, norms and trust, or simplify its definition and take only the social networks into consideration. These all depend on the aim of the researcher.

This study is part of a $\mathrm{PhD}$ thesis on social survey methodology, which aims to explore social capital in Turkey via a mixed-methods research with a gender sensitive point of view. In this context, the aim of this manuscript is to review the social capital concept and the indicators that are used to measure, and to identify the information and data source which is suitable for a measurement study at individual level social capital in Turkey. With this regard, this study compiles both the seminal theoretical and the empirical studies in the literature and presents them starting from the early 
theoreticians the social capital concept is revisited, afterwards scrutinizes the measurement studies, and in the aftermaths summarizes the significant points of these studies.

\section{SOCIAL CAPITAL CONCEPT}

Social capital concept is elaborated in the studies from various disciplines, such as sociology, economics, political science, education, psychology etc., which focus on the different aspects of social capital. Within this context, a highly complex concept is constituted.

The theoretical background of the social capital is found in the seminal theories such as Marx's 'class consciousness' theory, Durkheim's 'social integration and the sanctioning capacity of group rituals' theory, and Mill's argument on the 'value of connections between persons from dissimilar to themselves being significant sources of progress'. These theories laid the stones in the literature for the way through the social capital concept. And Tocqueville put forth the strength of civil associations in his widely known study, and without using the name of social capital he caused a significant impact on the development of the concept (Tocqueville, 1835; Putnam, 2000; Prakash, 2002).

The deployment of the concept in the early studies was complicated. There were studies that used the name 'social capital' for different concepts, such as race (Weatherly, 1910), labour force (Austin, 1918 quoted in Gabrielson, 2006), and stocks of physical capital (Marshall (1890) and Hicks (1942) quoted in Farr, 2004; Woolcock, 1998). In the early 1900s, Dewey (1915) and Hanifan (1916) used the term as it is understood today in their studies, both of which were in the area of education.

Social concepts generally have common constraints, such as having numerous ways of being defined and measurement methods, since the way theoreticians describe and researchers measure a social concept depends on the angle from where they look. Similarly, the complexity of the social capital concept led the theoreticians to elaborate from different point of views. Bourdieu sees social capital as a class issue and a private good, that the owner is expected to be a member of a certain class (Bourdieu, 1986; Ihlen, 2005; Eşki, 2009). Coleman puts that social capital is a kind of a public good that each person might benefit (Coleman, 1988; Eşki, 2009). While Bourdieu, Coleman, Portes and Lin, approach 
to social capital on the basis of an individual point of view, Putnam defines social capital as an asset for society possesses, and takes the term as a feature of communities, of which members of that community (individuals) contribute to and use (Bourdieu, 1986; Coleman, 1988; Portes, 1998; Lin, 1999; Putnam, 2000) On the other hand, Lin puts that social capital can be utilized by both individual and community (Lin, 1999). Additionally, Coleman, Portes and Lin emphasized that social capital is a relational asset, which means that a person must be related to others in order to possess social capital, and to benefit the advantage (Coleman, 1988; Portes, 1998; Lin, 1999).

The complexity of social capital concept prompted it to be elaborated in the studies related to civic associations, community actions, development economics and alike. In the mid-1960s, Olson put forth a theory of groups and public goods referring to the importance of networks (Olson, 1965). Although Olson did not used the name of the term, his study made a contribution on the rise of social capital concept. Especially, his theory made an impact on the establishment of an initiative within the World Bank with the name of 'Social Capital Initiative' in the late 1990s, which was dedicated to the studies of many theoreticians' in late 1990s and early 2000s (Collier, 1998; Dasgupta, 2000; Serageldin \& Grootaert, 2000; Woolcock \& Narayan, 2000; Grootaert \& van Bastelaer, 2001 and 2002). Regarding the social capital discourse within the area of development economics social capital was found effective against poverty and vulnerability (Woolcock \& Narayan, 2000).

Similarly, Organization for Economic Co-operation and Development (OECD) has been highly interested in the social capital concept, since the late 1990s (Healy et.al., 2001; Keeley \& OECD, 2007; Boarini et.al., 2014). Hence, OECD placed a great importance on social capital for the well-beings of nations and includes social capital in its measurements (OECD, 2011; 2013; 2015; 2017; 2020). In this regard, besides many studies, OECD has been publishing 'How's Life' report every two years which is based on 'four resources for future well-being' one of which is 'social capital'.

In the Turkish literature, the academic studies on social capital are mainly in the areas of business administration, economics, education, sociology and political sciences. In the area of economics, the focus is mainly on its relation to economic growth, or economic development (Basut, 2020; Bahtiyar, 
2017; Halıc1-Tülüce, 2013; Özcan, 2011). There are also studies on the impact of social capital on rural development (Keleş, 2014), and poverty (Tatl1, 2013a). In the area of sociology, the studies focus on urban-rural relations, gender, migration, and social media by Aydemir, Sümer, Baş, and Babacan (Aydemir, 2011; Babacan, 2012; Baş, 2018; Sümer, 2019). In the area of business administration, the relation between social capital and organizational behaviour, leadership, entrepreneurship is at the forefront of research subjects in the studies of Düzgün, Söylemez, and Çıpa (Düzgün, 2018; Söylemez \& Tolon, 2019; Çıpa, 2020).

\section{The Forms and Aspects of Social Capital}

Previously, the terms that have been used to define the difference between the various forms of social capital were generally 'dense networks', 'intensive relationships', 'closure of the social relations', 'weak ties', and 'outer community relations'. Coleman emphasized the benefit of closure of the social relations, while Burt urged the importance of weaker ties (Coleman, 1988; Burt, 1997).

The diversifying views of the theoreticians on social capital paved the way for the idea that "the effects of social capital vary according to its types', and the types of social capital started to become prevalently discussed within the literature. Putnam emphasized 'bonding' and 'bridging' social capital while explaining the changing form of social capital (Putnam, 2000). Woolcock and followingly the World Bank added 'linking social capital' into the literature as the third form of social capital (Woolcock, 2000; World Bank, 2000). Bonding and bridging forms of social capital are related to the ties between either individuals, communities or institutions, while linking social capital is defined as involving a kind of power relation between the individual/community and formal organisations, such as banks, insurance companies, and alike. The importance of this diversification among different forms of social capital is that, the impact of each form of social capital on the life of an individual, a community and a society would vary, since each form would contribute to these spheres in different ways (Warren et.al., 2001). However, the classification related to the forms of social capital is also complicated. The terms that describe the form of social capital are related to the formality (informal-formal) and strength (strong-weak) of a relation. Among different studies the conception of these forms might differ. For 
instance, taking into consideration Granovetter's 'strong and weak ties' which are redolent of bonding and bridging social capital respectively. Hodgkin and Putnam define bonding social capital via family and close friendship relations, while Warren and his colleagues define bonding social capital as 'withincommunity relations', such as the relations that church, school, etc., forges (Granovetter, 1973; Putnam, 2000; Warren et.al., 2001; Hodgkin, 2008).

Regarding the aspects of social capital, Krishna and Uphoff define networks as the structural aspect of social capital, and trust and norms as the cognitive aspect, stating that the structural aspect of social capital "facilitates mutually beneficial collective action through established roles and social networks supplemented by rules, procedures and precedents, while the [cognitive aspect] predisposes people toward mutually beneficial collective action on the basis of shared norms, values, attitudes and beliefs" (Krishna \& Uphoff, 1999, s. 7). This classification is embraced by other researchers, since it is prevalently utilized in the literature (Grootaert et.al., 2004).

\section{Critiques to the Social Capital Concept}

Most of the critiques of the concept mainly focus on the vagueness of the term and its measurement problems. Asserting the three aspects of the 'capital', which are 'extension in time', 'deliberate sacrifice in the present for future benefit', and 'alienability'. Arrow urges abandonment of social capital term, since it fails to embody the third aspect of the capital concept (Arrow, 2000). Solow argues about its immeasurable character, which is unlike physical -even human- capital, stating that "where the numbers would come from" (Solow, 2000, p. 7). Durlauf emphasizes its "vague definitions, poorly measured data, absence of appropriate exchangeability conditions, and lack of information necessary to make identification claims plausible" (Durlauf, 2002, p. 474). He also criticizes the disarray situation of assumed causes of social capital, which omit other factors in the empirical analysis related to measurement of social capital, and points that rather than being causal variables the variables that are employed are "choice variables" and "subject to constraints" (Durlauf, 1999, p. 3). Moreover, he adds that the direction of causality of social capital has not been cleared (Durlauf, 1999). Fine criticizes social capital for being an oxymoron and chaotic, and not being appropriate to be used together with the 
concept of 'capital' (Fine, 2010). He puts that the use of various indirect indicators such as crime rates, blood donation etc. (indicators other than social networks, trust and social norms that are generally defined as the direct indicators of social capital) paved way to a considerable confusion about the meaning of social capital as well as "the relationship between social capital and its outcomes" (Fine, 2001 quoted in Sabatini, 2009, p. 432).

Lin states that limited studies focus on the inequalities, and Addis and Joxhe mention that gender is not explicitly taken into consideration in the social capital literature (Lin, 1999; Addis \& Joxhe, 2016). There are studies related to the effect of social capital on entrepreneurship of women (Aaltio et.al., 2008; Byoun, 2013; Vosta \& Jalilvand, 2014; Toprakç1-Alp \& Aksoy, 2019). A number of studies are related to the social capital of specific women groups, and some studies discuss activity and network differences between men and women (Beyer, 2003; Lowndes, 2000; Addis \& Joxhe, 2016). Significant points of these studies are found as, women are generally part of networks based on kinship, child-care and/or friendship, while men are generally part of non-kin and colleague networks (Lin, 1999; Lowndes, 2000; Addis \& Joxhe, 2016); women who become part of non-kin networks are found to be more successful in working life (Byoun, 2013; Lin, 1999). However, the discomfort with data and measurement of the empirical researches on social capital is also valid for the studies that capture social capital from a gender point of view (Hodgkin, 2008).

The studies, which encompass gender in the social capital concept, raised different views on this issue. On one side, there are the ones who favour social capital on behalf of women, as a progressive concept (Addis \& Joxhe, 2016; Toprakç1-Alp \& Aksoy, 2019; Vosta \& Jalilvand, 2014; Byoun, 2013). On the other side there are studies which assume social capital as reinforcing gender inequality by paving the way to gender-based hierarchies to continue in the family and in the community (Molyneux, 2002; Mayoux (2001) quoted in van Staveren, 2002). And yet there is an idea which was revealed by Putnam, that asserts women's participation into labour market as one of the factors that led the decrease in the social capital of the community, and some others adopt the idea (Putnam, 2000; Cicel \& Heath (2001) quoted in van Staveren, 2002). 


\section{MEASURING SOCIAL CAPITAL ${ }^{3}$}

Social capital is found as an "elusive concept" to be understood empirically (Stone \& Hughes 2002a, p. 1), and this prompts the measurement of the concept highly controversial (Durlauf, 2002; Fine, 2010). However, as Schuller puts it, the question is not "whether ... something is measurable or not", but to what extent, under what conditions and at what cost is it measurable (Schuller, 2001, p. 21).

While there are numerous studies that examine a single aspect of social capital (either structural or cognitive), the multidimensional structure of social capital led some other researchers to an effort to comprehend via composite measures, specifically via building a composite index. (See Annex 1)

The empirical studies on social capital grow during the late 1990s and 2000s. During this period individual country studies and the studies of the World Bank (Grootaert \& van Bastelaer, 2002; Grootaert et. al., 2004) are the most prominent ones. Individual studies mostly concentrate on the studies in USA, Australia and Canada (Brehm \& Rahn, 1997; Paxton, 1999; Hall, 1999; Putnam, 2000; Glaeser et.al., 2001; Narayan \& Cassidy, 2001; Costa \& Khan, 2002; Stone \& Hughes, 2002a). In this period there are also a number of cross-country studies which focus on the selected countries (Knack \& Keefer, 1997; Beugelsdijk \& van Schaik, 2005). A number of the studies aim to present a tool for social capital measurement (Narayan \& Cassidy, 2001; Grootaert \& van Bastelaer, 2002; Grootaert et.al., 2004; Bullen \& Onyx, 2005; Nyhan-Jones \& Woolcock, 2007), of which some present this tool for the developing or the low-income countries (Grootaert \& van Bastelaer, 2002; Grootaert et.al., 2004; Nyhan-Jones \& Woolcock, 2007). The interest in the literature paved way for the government and international organisations to become interested in the social capital concept, such as National Bureau of Economic Research and Congress Joint Economic Committee in the USA (Hamilton et.al. 2016; US Congress Joint Economic Committee, 2018), Office for National Statistics in the UK (Ruston, 2003; Office for

${ }^{3}$ The details of the selected empirical studies that are elaborated under this title are presented in Annex 1.

SAD / JSR

Cilt / Volume 24 Sayı / Number 3 
National Statistics, 2020), Australian Institute of Family Studies (Stone \& Hughes, 2002a), as well as OECD and the World Economic Forum.

While measuring social capital, it is substantial to both examine the existing relationships and understand the structure of those relationships. In this regard, although not as prevalent as quantitative studies, there are several studies, which employ mixed-methods to measure social capital with an integrated view, such as Grootaert and van Bastelaer, Nyhan-Jones and Woolcock, and Hodgkin (Grootaert \& van Bastelaer, 2002; Nyhan-Jones \& Woolcock, 2007; Hodgkin, 2008).

Regarding the social capital measurement studies for Turkey, several studies analyse social capital across Turkey (Eşki-Uğuz et.al., 2011; Kızılkaya, 2017; Öztopçu, 2018); several studies analyse among countries (Akın \& Aytun, 2014; Vergil \& Bahtiyar, 2017; Karagül \& Dündar, 2006). A considerable number of studies focus on certain regions or cities of Turkey (Ardahan, 2012; Tatl1, 2013a and 2013b; Çalışkan et.al., 2014; Keleş, 2014; Keleş et.al., 2015; Erbaş1, 2015; Özpınar et.al., 2016; Türkseven \& Kutlar, 2019; Şentuna \& Çak1, 2020); and some studies focus on certain population groups (Ardahan \& Ezici, 2014; Uçar, 2016; Özdemir, 2008; Kartal et.al., 2017; Baş, 2018; Polatcan, 2018; Seki, 2019; Kuştepeli et.al., 2019; Paksoy \& Gül, 2019) (See Annex 2). Several studies measure social capital via a composite index (Uçar, 2016; Ardahan, 2012; Tatlı, 2013a and 2013b; Ardahan \& Ezici, 2014; Çalışkan et.al., 2014; Erbaş1, 2015; Kızılkaya, 2017; Öztopçu, 2018; Polatcan, 2018; Paksoy \& Gül, 2019; Şentuna \& Çak1, 2020). Most of the studies investigate social capital from the perspective of trust. However, to the extent known, there is not an across country study which both takes into account the three dimensions of social capital, namely networks, trust, and norms, and utilises quantitative and qualitative analysis together.

\section{Empirical Studies with Single Aspect of Social Capital}

The prominent studies that examine a single aspect of social capital are the studies of Knack and Keefer, Glaeser and his colleagues, Costa and Khan, Patulny, Xue, Christoforou, Weaver and his colleagues, Addis and Joxhe, and Hamilton and his colleagues (Knack \& Keefer, 1997; Glaeser et.al., 2001; Costa \& Khan, 2002; Patulny, 2003; Xue, 2008; Christoforou, 2011; Weaver et.al., 2013; Addis 
\& Joxhe, 2016; Hamilton et.al., 2016). Among these single-aspect studies, Glaeser and his colleagues, Christoforou, and Addis and Joxhe take into consideration a single indicator that is 'group/organisational membership', excluding Hamilton and his colleagues which take 'trust' into consideration.

Knack and Keefer use 'trust' and 'norms of civic cooperation' as the indicators, and analyse the relation between these indicators and economic activity (Knack \& Keefer, 1997). They also analyse the relation between groups and trust as well as civic cooperation, and found that groups that have distributional goals (such as trade unions and professional associations) are associated with trust and civic cooperation, while groups that don't have distributional goals (such as education, arts, music, cultural activity groups) have no effect on trust and have negative effect on civic cooperation. However, they emphasise the lack of their data which "do not permit ... to convincingly distinguish between socially efficient and inefficient memberships and activities" (Knack \& Keefer, 1997, p. 1274). However, the framework of their study that limits the concept of social capital to cognitive aspect, leads to a restricted analysis. Hence, taking into account the findings of Knack and Keefer it might be inferred that group membership is not a sufficient indicator by itself, it is needed to be assessed together with the quality of these memberships, and network issue should be considered in a broader extent, involving many sorts of social relations that reflects activities with others, not limiting to memberships in groups.

Having a different point of view, Glaeser and his colleagues examine "the social capital investment decision of individuals", employing an economic approach that "the traditional models of investment in human and physical capital" have employed (Glaeser et al, 2001, p. 5). With this point of view, they define social capital as a trait of an individual, which facilitates the market and non-market benefits that an individual obtains, and researches at the individual level. They use 'organisation membership' as the indicator of social capital, and analyse the formation of social capital using a model of 'optimal individual investment decisions'. They find that the relationship between social capital investment and age has an invert -U shape, social capital investment declines with expected mobility, and social capital investment is higher among people who have occupations with greater returns to social skills, who are homeowners, live closer to each other, and who invest in human capital. 
Christoforou explores the relation between the individual and the aggregate factors of social capital in the selected European countries (Christoforou, 2011). Christoforou employs 'group membership', both formal and informal group membership, as the indicator of social capital, and she uses it as an index value. Regarding the individual aspect, Christoforou finds that having higher levels of education and income, and being male increases the probability of group membership, but age does not have a common trend on group membership. Regarding the aggregate aspect, Christoforou finds that among the socio-economic indicators 'per capita GDP' has a positive impact on the probability of group membership, while 'income inequality' and 'unemployment rate' have a negative impact; and among the socio-political indicators 'social trust', 'trust in political institutions' and 'corruption' have positive impact, while 'violation of political rights' has a negative impact on group membership. The methodology of utilizing the 'trust', 'trust in political institutions', 'corruption' and 'violation of political and civic rights' as the independent variables for the analysis seems arguable, since these indicators are defined for trust and norms aspects of social capital in the relevant literature, and in this regard it might be better to take them into consideration among the dependent variables.

Similar to the approach of Glaeser and his colleagues, Addis and Joxhe investigate how the accumulation of social capital differs according to sex and age. Employing the data of Italian Multiscopo Survey and comparing the social capital stock of two years, 1997 and 2011, they seek to find the changes in the social capital stock between these two years (Glaeser et.al., 2001; Addis \& Joxhe, 2016). They use 'organisation membership' as a stock indicator for social capital, asserting that organisation membership refers to 'linking social capital', which they also define as 'weak-ties'. They find that women's social capital investment continuously declines after the age of 18 , which is always under the social capital investment of men, that increases up to the age of 45 and starts to decline after 45 , and the gender gap narrows approximately 10 percent from 1997 to 2011. While the findings of Addis and Joxhe is significant in terms of revealing the gender difference in social capital, the scope of social capital they defined has some constraints. First of all, linking social capital, which is accepted in the literature as the relation between the more powerful and the less powerful, might also exist within business relations. 
Second, weak-ties cannot be induced to organisation membership, since it might also be realised within other type of relationships. Third, organisation membership might also involve strong ties, which might be defined as bonding social capital. Within this context, it will not be the best possible option to define organisation membership with only linking social capital, and limit it into weak-ties.

Hamilton and his colleagues search the share of social capital within the production of wealth, and utilise 'trust' as the primary element of social capital (Hamilton et.al., 2016). Employing the data of the Gallup World Poll, European Social Survey and the World Values Survey, they find that for the selected countries, social capital has the second highest share in the production of wealth among the four types of capital (physical, natural, human and social capital).

Kizllkaya analyses the relation between social capital and economic growth, accepting 'economic trust' as the main element of social capital (Kızılkaya, 2017). In this context, Kızılkaya employs 'contract viability', 'law and order', 'economic risk assessment', 'financial risk assessment', 'political risk assessment', 'democratic accountability', 'government stability' and 'legislative power' as the indicators for the economic trust and calculate a social capital index using the data related to these indicators. The main finding of Kizılkaya's study is that social capital has a significant effect on economic growth. On the other hand, regarding the indicators that have been employed, it is seen that the social capital that is analysed in this study is related to economic, financial and political relations, however the social relations have not been included.

Vergil and Bahtiyar analyse the relation between social capital and economic growth within a model, which involves physical capital, human capital and trade openness for 28 EU countries and Turkey between 1980 and 2014 (Vergil \& Bahtiyar, 2017). The indicator for social capital is defined as generalised trust, and the indicators for physical capital, human capital, trade openness and economic growth are defined as physical capital stock, education expenditure per capita, ratio of export to GDP and GDP per capita respectively. They find that social capital significantly and positively affects economic growth just as the other dependent indicators do. 
Karagül and Dündar examine the relationship between social capital and human development (Human Development Index), competitiveness (competitiveness level), justice (justice level) and income distribution (Gini coefficient) (Karagül \& Dündar, 2006). The aim of the study is to find how the other variables affect social capital, so social capital is determined as the dependent variable in this study. They define social capital as the generalised trust, and find significant relations between each independent variable and generalized trust.

\section{Empirical Studies with Two Aspects of Social Capital}

Asserting the lack of 'a link between theory and measurement' in the existing empirical studies which led them to employ improper indicators for measurement, such as voting, Paxton puts that the studies which rely on a single indicator is against the multidimensional structure of social capital, hindering the identification of fatal indicator usage, and in her empirical study she accepts social capital involving two components: (1) Objective ties which indicates associations between individuals, (2) Subjective ties which indicate the characteristics of the ties as being "reciprocal, trusting, and involving positive emotion" (Paxton, 1999, p. 93). She finds that while the overall level of trust declines within the time period, level of associations does not decline. Paxton asserts that individual and group-level social capital are linked, stating that "the social capital in a [certain] community could have benefited any individual member" leading to individual-level good, while the same group could have "positive impact on all their members" for collective problems leading to group-level good (Paxton, 1999, p. 94). In this sense "[t]he goods produced by social capital can occur at different levels of the social structure" (Paxton, 1999, p. 93). For instance, when "a mother asks a friend to baby-sit rather than hiring a babysitter ... social capital is an individual, private good can be used for economic gain or another private outcome" (Paxton, 1999, p. 94). This assertion of Paxton is an advancement within the argument of social capital being either a public or a private good, since it points to circumstantiality of the situation. Therefore, considering social capital as a private or a public good would depend on the level of analysis, whether it is micro (individual), or meso (community) and macro (national). 
Costa and Kahn investigate the trends in social capital in the United States between 1952 and 1998, in order to understand the situation of social capital, as well as whether it has been decreasing as dramatically as Putnam asserts (Costa \& Kahn, 2002; Putnam, 2000). With this aim, they analyse social capital 'within the home', involving 'entertaining and visits with friends, relatives and neighbours, and 'outside the home (or 'within the community')', involving 'volunteering' and 'membership in organisations'. In addition, they examine whether the particular trend changes for men and women, and for those who are college educated and non-college educated, emphasising these two groups supply many of the volunteer workers (Freeman, 1997 quoted in Costa \& Kahn, 2002, p. 2). Furthermore, they seek to find the effect of income, race, and ethnic heterogeneity within communities. They utilise ten different data sets, three of which are time-use studies. The variables they employ are related to membership, volunteering and relations with family and friends, as well as the duration and frequency of interactions. They spot a decline in both types of social capital with different paces. While the decline in 'within home social capital' is dramatic, the decline in 'outside home social capital' is moderate. Looking at the situation between the two sexes, they reveal that the decline in women experienced in both types of social capital is higher than men, and between the two types of social capital 'within home social capital' declines more, a trend which is explained by Costa and Kahn as a result of 'greater labour force attachment". They also find that the decline in the 'outside the home social capital' is related with increasing income inequality, ethnic heterogeneity and the decline in the women's social capital'.

Eşki-Uğuz and her colleagues examine social capital employing the data of a survey which was conducted under a project named "A Field Study on Determining Turkey's Social Capital Stock and Social Capital Profile of the Society" which is supported by the Scientific and Technological Research Council of Turkey (Eşki-Uğuz et. al., 2011). The universe of the survey is the population aged 18 and over, sampling frame is voter records and the sampling size is 1600 individuals. They investigate social capital through the aspects of "attitude towards civil life and civil values", "trust and sense of security", "social tolerance", "network characteristics" and "neighbourhood relationships". The findings are evaluated based on the answers to the questions under each aspect. In this context, analysis is limited to 
the evaluation of each answer individually, and the relation between these aspects emphasised narratively rather than empirically. Thus, the study provides an outlook for social capital in Turkey.

The OECD 'How's Life?' studies have gradually developed the method of measurement of social capital in each report between 2011 and 2020. Within the scope of these reports, social capital is accepted to be effective on both current and future well-being as being one of the four types of capital, which form 'capital stock'. However, the study has a significant constraint, as it is aimed to cover the data of OECD countries, which is quite difficult to gather with the same standards. In this regard, social capital is defined as one of the dimensions of future well-being and the data used to capture social capital is related to 'trust', 'cooperative norms' and 'volunteering'.

\section{Index Studies}

Although criticized by some researchers, index usage for social capital measurement is prominent, especially among the studies, which assert the importance of social capital on the economic and social life (Putnam et.al., 1993; Putnam, 2000; Putnam, 2001; Beugelsdijk \& van Schaik, 2005; van Beuningen \& Schmeets, 2013; US Congress Joint Economic Committee, 2018; Legatum Institute, 2007-2020). However, some researchers who criticise index usage for social capital measurement partially disagree with index building. For instance, Grootaert and van Bastelaer construct a social capital index to show why index building is not suitable for social capital measurement, and conclude that although index usage is not appropriate for their study, multivariate index (which is a kind of composite index) building is correlated with the interaction of the indicators employed, and justify the usage of a multiplicative index if the effects of the indicators are thought to interact (Grootaert \& van Bastelaer, 2002).

One of the seminal studies, which involve social capital index belongs to Putnam. By employing the data for informal networks and data related to altruism in addition to the data of formal club membership, Putnam computes a social capital index, a single measure for social capital (Putnam, 2000). Besides, Putnam used the data for a number of lawyers per 10.000 employees and data related to crime as proxy, to examine the negative sides of the trend in social capital. Putnam finds that the level of informal networks, number of formal club membership and voluntary activities have been in a decline 
since 1965, while number of lawyers have been doubled. Putnam also finds that in various states where social capital index level is lower, crime rates are higher. Putnam translates this as a "massive transformation of social bonds in America" (Putnam, 2001, p. 48).

Referring to the multidimensionality of the social capital concept, and questioning the validity of a single index to measure social capital, Stone and Hughes present an extensive study on this issue (Stone \& Hughes, 2002a). Among the problems of the existing empirical studies on social capital, they mention using 'the single item/index method' and 'not recognising the variability social capital among network types and social scales', and they point to the importance of quality and structure of social capital. Their empirical study puts a significant effort to examine a proper way to measure social capital. They measure social capital in different network types and social scales, namely 'informal realm, 'generalised realm', and 'institutional realm'. As the output of their analysis, the items they employed are "grouped into several principal components" rather than a "cohesive measure", and they assert that rather than using a single index to measure social capital, a composite measure of key dimensions of social capital is much more reliable (Stone \& Hughes, 2002a, p. 22). They also find that the different "types of relationships people have in different spheres of their lives" is important "to understand the complexity of social capital" (Stone \& Hughes, 2002a, p. 26). Although they determine the single item approach as faulty and failing to recognise the multidimensionality of social capital, and the index approach as "prevent[ing] analysis of how the various parts of the concept interact" (Stone \& Hughes, 2002a, p. 18). They mention that some elements of social capital, such as norms of trust and reciprocity, can "be grouped to represent overall dimensions of social capital" (Stone \& Hughes, 2002a, p. 23). And they emphasise that distinguishing the dimensions of social capital may not be important, due to the context of the research.

Beugelsdijk and van Schaik explore the relationship between economic success and social capital, in the 54 regions of 7 Western European countries, namely Italy, France, Germany, Spain, the Netherlands, Belgium and the United Kingdom, via constructing a social capital index (Beugelsdijk \& van Schaik, 2005). They use 'trust', 'passive group membership' and 'active group membership (doing 
voluntary work for certain group)' in their index, and find that while there are noteworthy differences in the social capital index levels among the 54 regions, there are also "a positive and significant relationship between social capital and economic performance" in the mentioned regions (Beugelsdijk \& van Schaik, 2005, p. 19).

The Social Capital Index that is calculated by the Legatum Institute is prominent due to its usage among the sub-indices of the 'Global Competitiveness Index', which is announced by the World Economic Forum. Legatum Institute announces 'Prosperity Index' aiming to measure the national prosperity of countries examining the indicators related to institutional, economic, and social wellbeing of these countries, and 'Social Capital Index' is one of the eight sub-indices of this index. The variables that have been used in the calculations were changed within time. In the 2007 Report the relevant subindex was named as 'Community Life' and social capital was associated with 'trust', in the 2008 Report the associated indicators involved volunteering, donation, membership, and trust. In the 2009 Report the name of the sub-index changed with 'Social Capital Index'; in the 2010 Report two areas were defined under social capital sub-index, as 'social cohesion and engagement' and 'community and family networks'; finally in the 2019 Report the social capital sub-index involved five areas, 'personal and family relationships', 'social networks', 'interpersonal trust', 'institutional trust', and 'civic and social participation', under which 17 indicators take place in total. The change in the way social capital examined and the extension in the number of indicators employed implies an ongoing change in the perception of social capital within time. In this regard, as it was mentioned in many studies, social capital is still a progressive concept.

Öztopçu investigates the relationship between social capital and regional development (Öztopçu, 2018). In order to find this relationship, first of all, Öztopçu constructs social capital index of the 26 NUTS 2 regions, using divorce rate, higher education graduation rate, voter turnout, migration rate, suicide rate and number of theatres. Afterwards, Öztopçu searches for a significant relation between the Social Capital Index and Socio-Economic Development Index values (which was formerly calculated by the Ministry of Development) of the regions. Öztopçu finds a significant relation between social 
capital and socio-economic development. Although the six indicators employed for social capital index calculation might have an indirect relation with social capital, they also have a direct relation with social development which has also impact on economic development, especially higher education rate and migration rate. Whereas the major characteristics of social capital such as networks, group membership, volunteering or trust is not involved in this social capital index, which is thought to be a significant shortcoming.

Akın and Aytun study the direction of the causality relation between unemployment rate and social capital in 41 countries, in which Turkey is not included, for the period of 1981-2012 (Akın \& Aytun, 2014). They recognize linking social capital, as the form of social capital, which is effective on job finding, compared to the other two forms of social capital, bonding and bridging, assuming that these two forms of social capital might lead to high clientelism and negative externalities. They accept linking social capital formed through effective communication between individuals, thus define land phone, cell phone and internet use as the indicators of linking social capital, and using communication data, they build an index, as the indicator for social capital. They find a relationship between unemployment rate and social capital, of which the direction is from social capital towards unemployment rate. However, generalizing bonding and bridging social capital as leading clientelism and negative externalities, and thus omitting networks, trust and norms from the analysis and would lead to imperfect analysis.

\section{Measurement Tool Studies}

With their empirical study, Narayan and Cassidy provide "a set of statistically validated survey questions for measuring social capital in developing communities", and use this questionnaire in the surveys they conducted in Ghana and Uganda (Narayan \& Cassidy, 2001, p. 61). They define the determinants, dimensions and outcomes of social capital prior to their empirical work, afterwards check their relevance and relation, and re-define them. They conclude communication and empowerment as the determinants; government competence, government honesty and corruption, quality of government, peace and safety, and political engagement as the outcomes; and characteristics, generalized norms, trust, togetherness (how well people get along), everyday sociability, neighbourhood connections and 
volunteerism as the dimensions of social capital. A significant finding of this study is that 'general trust' and 'trust in institutions' measure different constructs. Taking this into consideration, it might be said that it will not be proper to use these two indicators interchangeably. Hence such constraints might also appear with a much closer look on the indicators, and this led us to the use of appropriate indicators for the certain design of the empirical study. More clearly, while using a certain indicator in lieu of some other indicators because of non-existence, it should be born in mind that, that a certain indicator might not be the proxy of the other.

The study of Grooteart and his colleagues present a questionnaire, the Social Capital Integrated Questionnaire (SC-IQ), to be applied in the developing countries to measure social capital (Grooteart et.al., 2004). The survey focuses on the measurement of social capital at the individual level, and involves six sections which reflect the dimensions of social capital: 'group membership and networks', 'trust' and 'norms', 'collective action and cooperation', 'information and communication', 'social cohesion and inclusion', and 'empowerment and political action'. While Grootaert and his colleagues present a framework for social capital measurement, the indicators that will be used to measure social capital in a specific community and the method that will be used for the analysis are left to the researcher who would employ SC-IQ. On the other hand, emphasising the constraints of quantitative measurement of social capital, they state that "the process of creation (and destruction) of social capital will be understood better by means of a variety of qualitative in-depth studies" (Grootaert et. al., 2004, p. 17).

Bullen and Onyx conduct a survey to measure social capital (Social Capital Questionnaire-SCQ) in five communities of New South Wales, Australia, and present a measurement tool with a guide for the future practitioners (Bullen \& Onyx, 2005). The aim of the study is to 'identify a good set of questions ... [to measure] social capital' in order to identify the attitudes, behaviour and knowledge that are related to social capital, the elements of social capital, and whether social capital is correlated with gender and other demographic variables (Bullen \& Onyx, 2005, p. 13). In general, the questions are related to 'relations with friends, neighbours and local community organisations', 'attitudes', and 'behaviours'. Using factor analysis, the underlying dimensions of social capital are investigated and the 
eight elements for social capital are found as 'participation in local community', 'proactivity in a social context', 'feelings of trust and safety', 'neighbourhood connections', 'tolerance of diversity', 'value of life' and 'work connections', while the questions related to 'government', 'opposing to a generalised reciprocity', and 'isolation from or opposing to the social context', are found irrelevant to social capital.

McAloney and her colleagues implement the questionnaire that Bullen and Onyx developed, the SCQ, in the Northern Ireland (McAloney et.al., 2011; Bullen \& Onyx, 2005). They include an additional dimension to the SCQ and exclude some of the indicators. And they conclude that "variations in the factor structure of the SCQ suggest that social capital may be structured differently in different cultures, and highlights the need to develop measures specific to the country or culture of interest" (McAloney et.al., 2011, p. 113).

\section{Mixed-Methods Studies}

The study of Grootaert and van Bastelaer present an integrated measurement tool for social capital, which involves both quantitative and qualitative measures, namely 'Social Capital Assessment Tool' (SOCAT) (Grootaert \& van Bastelaer, 2002). The key objective is "to contribute to the understanding of how community, household, and organization-level measures of social capital interact with other development indicators [(such as poverty, education, health, infrastructure, crime and violence)] and thus to assess whether social capital contributes to or erodes economic and social development" (Grootaert \& van Bastelaer, 2002, p. 24). With this in mind, measurement of social capital is seen as a supplementary to measurement of the effect of certain development projects/activities that are conducted within a community, and it takes into consideration both structural and cognitive aspects of social capital. SOCAT consists of three sequential sections: community profiles, household survey and organizational profile. First section involves qualitative and quantitative data gathering steps, 'openended community discussions' and 'structured community interviews'; second section involves a quantitative data gathering step, 'household survey'; and third section involves two steps, 'semistructured interviews' and 'score-sheets'. The two pilot studies of SOCAT were conducted in some of the communities of Panama and India. Since SOCAT gathers data about the social capital of a specific 
community, and its level of analysis is meso, its findings would be at community level. Although SOCAT is presented as an integrated measurement tool, the methodology related to the integration of the qualitative and quantitative phases of the analyses is not discussed within the study. It is mentioned that within the scope of SOCAT index building was not preferred since "the indicators capture different dimensions of social capital that are each relevant in their own right for understanding social capital" (Grootaert \& van Bastelaer, 2002, p. 56). On the other hand, multivariate index (which is a kind of composite index) building is mentioned as being correlated with the interaction of the indicators employed, and using a multiplicative index is justified even if the effects of the indicators interact.

Nyhan-Jones and Woolcock offer a tool to measure social capital via mixed-methods research, at micro level (household or community level) (Nyhan-Jones \& Woolcock, 2007). The dimensions they offer to examine social capital are the same six dimensions as Grootaert and his colleagues define (Grootaert et.al., 2004). Moreover, they employ these six dimensions for both qualitative and quantitative phases. Although they suggest an iterative process as an ideal method, they mention that the sequence of the qualitative and quantitative phases of a mixed-methods research depends on both "the specific nature of the issue [that is] under investigation" and the limit of the research budget (NyhanJones \& Woolcock, 2007, p. 2). Within this context, they suggest the qualitative phase of the study to be conducted "to explore issues of process and causality" of social capital, and present sample questions related to each dimension that the reader might benefit. As the methods for qualitative research on social capital, they emphasise 'participatory method' (which involves group discussions conducted among the representatives of the major subgroups in the community), 'key-informant interviews' and 'participant observation'. Regarding the quantitative phase of the study, they present a questionnaire, which involves selected questions from the SC-IQ and a number of additional questions. On the other hand, they do not address how to integrate the outputs of qualitative and quantitative phases within the study.

Hodgkin criticizes the empirical studies on social capital for measuring only "the extent of participation in associational life" and "having little consideration for the informal networks to which people belong", while emphasizing the possible "different types of social capital that include 
participation in both informal networks and more formal associations", and conducting a mixed-methods research (Hodgkin, 2008). Taking into consideration the constraints of the present empirical researches, Hodgkin employs quantitative and qualitative methods together, referring to the arguments of former researchers related to mixed-methods research that "give[s] a more powerful voice to women's experiences" (Brannen (1992), Epstein et al. (1991), Oakley (1999), Shapiro et al. (2003) quoted in Hodgkin, 2008, s. 299). Hodgkin's study seeks to map 'the different patterns of participation' based on gender, and to explore how 'the role of mother' alters the activities that women are involved in, and the reasons for this. Hodgkin performs an explanatory sequential design, and conducts the quantitative analysis in the first place to describe and explain the "aspects of the differences between men and women on social, community, and civic participation" (Hodgkin, 2008, p. 303). Within the quantitative phase, Hodgkin employs 'simple random sampling method', and sends a survey questionnaire to 4.000 households from a database that local government provided. Then conducts the qualitative analysis to "[explore], from the viewpoint of women, their processes of interacting in their social, community, and civic worlds and how they felt about their lives and the activities in which they became involved" (Hodgkin, 2008, p. 300). The participants of the qualitative phase are selected via sending an invitation form to the respondents of the first phase. Subsequently having the results of both phases, Hodgkin evaluates the outputs through an integration point of view. Within this context, Hodgkin finds that while quantitative analysis reveals different social, community group and civic participation patterns for men and women, qualitative analysis shows that 'good mother' idea lies behind the motivations for participation. Another finding of this integration process is that, while quantitative results "highlight women's increased role in informal social participation, social participation in groups, and community participation", qualitative results reveal that most of the women feel excluded when they try "to participate at a civic level”. In this regard, the study of Hodgkin displays an example of how qualitative analysis shed light on the findings of quantitative analysis, and explicate them in-depth. 


\section{DISCUSSION}

Looking at the dimensions and indicators that are used in the measurement of social capital it is seen that a consensus has not been shaped in the literature. While in several studies only one aspect of social capital is taken into account, with either a single indicator or more than one indicator, in many other studies all of the aspects are considered, and sometimes with a wide range of indicators (See Annex 1). It is understandable for the instances in which theoretical framework of the study necessitates specific indicators, some indicators might not be taken into consideration. However, excluding some aspects or dimensions of the social capital without drawing the picture of this necessity would be misleading for the reader. Nevertheless, Paxton associates the usage of improper indicators for social measurement with absence of "a link between theory and measurement", emphasising that in case of such absence identification of fatal indicators might occur (Paxton 1999, p. 90). An example of this is the situation related to 'child care activities', which are accepted as a social capital development activity withinhousehold, such as by Coleman who asserts that these activities support the social capital of the children, and considering the remark, Gray takes 'child care activities within the household' among the elements of social capital development (Coleman, 1988; Gray, 2003). On the other hand, the link between child care activities within the household and social capital development might not be relevant for the giver of the care activity, while it might be relevant for the receiver of the care and for the society. Regarding this example, we see that the framework of the analysis is highly important on the decision of the indicators for social capital.

There are significant findings of the empirical studies which highlight how to decide the details of a social capital measurement analysis. One is 'not all types of social capital are good for the society' (Paxton, 1999; Putnam, 2001). For instance, mafia relations are also a type of social capital, due to their structure which pursue trust, norms and communication ties. However, these types of social structures are not desirable for a society. Similarly, a tribe or extended family, which restricts the outer connections of an individual being intolerant for the outer relations, might also, be a bad type of social capital. In this regard, if we only take into account the existence of trust, norms and/or communication ties, this 
might lead us to a fatality of measuring a high level of social capital for these types of undesirable or constrictive relations. On the other hand, taking only into consideration the networks and/or trust either 'between groups' or 'within group' would also lead a biased output, since without both 'between groups' and 'within group' networks and trust, we might define the ties and trust that -for instance- tend to cause criminal activities as implying high social capital (see Paxton, 1999). Considering the former discussions on this issue, it would be better to take not only the structural aspect of social capital (networks), but also the cognitive aspect (trust and norms) into account in the measurement, and among not only within group but also between groups.

Therefore, the forms of social capital are also important on the benefit of society and/or individual. Regarding the community level, OECD defines this situation with the intensity of bonding and bridging social capital that exist within a certain community: "Too much bonding in the absence of bridging social capital can lead to "in group/out-group" dynamics, leading to the exclusion of those outside the bonding group (OECD, 2011). Networks can also foster values that are detrimental for society, as is the case with mafia or terrorist organisations" (OECD, 2011, p. 171). Thus, it becomes essential to explore the intensity of different forms of social capital. Regarding the individual level, intensive existence of bonding social capital, which mostly consists of strong ties within familial relations, and absence or scarce existence of bridging social capital, which mostly consists of weak ties within -for instanceorganisational relations might hinder an individual to increase his/her welfare by restraining him/her into a narrow network of relations. While analysing social capital, it would be much more appropriate to endorse either strength of ties or power relations as the classification level for the forms of social capital. In this regard, bonding and bridging social capital are more clear forms that are easy to differentiate from one and another.

Findings of a number of studies demonstrate that development of relations between a community and powerful parties is significant (World Bank, 2000; Narayan \& Cassidy, 2001; Warren et.al.2001; Onyx \& Bullen, 2005 quoted in Warren et.al., 2001). However, if the opportunities of poor communities to connect with powerful parties are just a few, this would lead to a vicious circle. In this regard, it 
becomes important to understand whether that specific community or the individuals who constitute that community have the capability to grab the chance to connect with the powerful when that chance is provided. Therefore, the question should not be limited with the issue of current situation related to 'the connection with powerful', but it should involve 'whether possible connections will be provided', and 'whether the individuals will be capable of grabbing the chance when it is appeared and of sustaining that connection'. Hence, such a prediction might be made via examining current structure of the relations.

Other significant findings are as follows: membership should be considered with the quality of membership, and the issue of network should be considered involving many sorts of social relations (Knack \& Keefer, 1997); the place of activity, whether there is anyone to accompany during this activity, and if yes with whom the activity performed is a noteworthy information related to understand the significance of the activity towards social capital development (Ruston, 2003); index building is not faulty for every study, since the significant points are 'the framework of the research study' and 'getting the cohesive items together' (Grootaert \& van Bastelaer, 2002). Hence while determining the extent of the information that would be considered in the processes of data/information collection and analysis, the previous findings should be taken into consideration.

Various data sources are employed to explore the social capital concept, since there is no broadly excepted 'data' or 'variable' set to analyse social capital. Most of the time the data selection depends on the target group of the study. As McAloney and her colleagues put it "These measures range from proxy items assessing a single, or combinations of particular aspects of social capital such as trust, network density or participation ..., to comprehensive measurement tools allowing for fuller assessment of social capital and its consequences" (McAloney et.al. 2011, p. 114-115). Providing "data related to the nonmarket sphere of economic and social activity", Time Use Surveys present a worthwhile source for measuring social capital (Garcia-Diez, 2013, p. 26). Indeed, involving data on how individuals spend their time within and outside the household in a day or two, Time Use Surveys present valuable 
information about activities which might be evaluated as the marks of social capital, and indicate the attitudes and behaviour of the individuals.

The data of time-use should be analysed in detail in order to comprehend the scope of an activity, whether it affects social capital development or not, i.e. including the place of activity into the analysis, as well as considering whether the activity is carried out with someone, and if so with whom. For instance, child care activity might be recorded for bringing the child to a playground and alike, an activity which might also lead to the socialization of the care giver. In such a case, the environment that the activity is realised should be considered. Ruston mentions these two aspects of time-use data, which provide additional contextual information about social capital, as 'social space' and 'social circle' respectively ${ }^{4}$ (Ruston, 2003). Indeed, revealing the details of 'daily social life', time-use surveys make it possible to investigate the individual's social relations, and those social relations inform us about the individual's social capital.

On the other hand, it is understood that the core elements of social capital are networks, trust and norms. Moreover, although time-use surveys provide a good extent of information about networks due to its data which inform the activities that respondents involve, as well as the frequency and duration of this involvement, it is not suitable to gather data on trust and norms which are subjective concepts, and so which are better to be provided via appropriate methods for subjective phenomena. Indeed, trust and norms consist of the respondent's perception, and may be corrupted more easily due to the interviewer or respondent bias. Indeed, even the tailor made surveys might entail representativeness problems and lack of information related to the individual attitudes on trust and norms of reciprocity, which are significant information to capture social capital.

In addition to the need for objective and subjective data and information gathering methods, as Narayan and Cassidy and Stone and Hughes have demonstrated in their studies that, it is quite

4 The terms of 'social space' and 'social circle' belongs to Harvey and Taylor (2001) quoted in Ruston (2003, p. 3), in reference to Lewis (1951).

$\mathrm{SAD} / \mathrm{JSR}$

Cilt / Volume 24 Say1 / Number 3 
complicated to separate the determinants, dimensions and outcomes of social capital since these might be intertwined (Narayan \& Cassidy, 2001; Stone \& Hughes, 2002a). Untangling this intertwinement needs to seek for an exploration that goes beyond the explanatoriness of the quantitative data. Hence, following the identification of the social capital potential of the individuals, in-depth knowledge is needed to complement the quantitative information that time-use data presents, and the most appropriate way of gathering this in-depth complementary data is found as best via qualitative methods. In this regard, it is meaningful to conduct the measurement of social capital in three steps: first, to measure the more concrete part of the concept via quantitative analysis, second, to measure the more subjective part of the concept via qualitative analysis, and third, integrate the findings of the quantitative and qualitative analyses.

\section{Last Words}

Social concepts are always complicated to be comprehended, due to their abstract and intangible structure. In the last decades there is a wind towards elaborating social concepts multidimensionally and by means of an integrated research process. Indeed, social capital involves many facets, which makes it difficult to be understood through a single analysis process. Hence, as mentioned in the previous section, quantitative data does not help to clearly understand, for instance, the dimensions of the social capital, the different forms of it, as well as the density and diversity of these forms. In this regard, while quantitative analysis process is expected to reveal how the picture of social capital is seen in the first place in a certain social context, qualitative analysis process is expected to provide information to understand its intensity and quality. Thus, social capital, as an elusive subject, which is still discussed within the literature in terms of how to be handled, is a good candidate to be evaluated via mixedmethods research. Regarding the quantitative phase of a research on social capital, time-use surveys provide a broad information that enable to investigate the various aspects of social capital to be measured. However, as mentioned above, time-use surveys provide limited data on 'trust' and 'norms' components of social capital. Hence, either designing a specific research on social capital or including 
a specific part into an ongoing research to collect both quantitative and qualitative information might be considered in order to gather directly related and broad information regarding social capital. 


\section{ÖZET}

Bireyler arasındaki sosyal ilişkilerin bireyler ve toplum açısından sağladığı faydayı anlatan sosyal sermaye, yazında birbirinden farklı açılardan ele alınması nedeniyle karmaşık bir kavram olarak görülmekte ve ölçümü de pek çok farklı yöntemle yapılmaktadır. Sosyal sermaye konusunda çalışma yapan araştırmacıların kullandıkları teoriyi çalışmalarına -çoğunlukla- tam olarak yansıtmamaları ve sosyal sermayeye ilişkin farklı ya da eksik boyut ve/veya göstergeleri dikkate almaları uluslararası yazında sıklıkla dile getirilen bir eleştiridir. Sosyal sermayeyi ölçerken sosyal sermayenin boyutlarının ve inceleme düzeyinin çalışmada kullanılan sosyal sermaye teorisi çerçevesinde tanımlanmasına ihtiyaç duyulmaktadır. $\mathrm{Bu}$ kapsamda araştırmacının, araştırmanın düzeyine ve çalışmanın varsayımlarının arkasinda yatan teoriye karar vermesi gerekmektedir.

Sosyal sermayenin ölçümünde öncelikle yapısal ve bilişsel boyutların birlikte ele alınması önem taşımaktadır. Diğer taraftan, ele alınan boyutlar itibariyle ilk bakışta ölçüme dahil edilmesi ya da dışarda bırakılması gerektiği düşünülebilecek bazı göstergelerin, çalışmanın çerçevesi dolayısıyla kapsam dış1 bırakılabileceği veya ölçüme dahil edilmesi gereken durumlar da söz konusu olabilmektedir. Sosyal sermayenin tüm biçimleri toplum açısından faydalı olmayabilmektedir. Örneğin yasa dışı faaliyetlerin yürütüldüğü bir topluluktaki bireylerin ilişkiler ağı yüksek bir sosyal sermayeyi çağrıştırabilecektir, ancak söz konusu sosyal sermaye her ne kadar bireyin çıkarı açısından faydalı olsa da toplum açısından zarar vericidir. Dolayısıyla ölçümde bu tür durumların dikkate alınması önemlidir. Benzer şekilde, sosyal sermayenin türleri olan bağlayıcı ve köprü kurucu sosyal sermaye kapsamında bireylerin yakın çevre, uzak çevre ilişkilerinin yoğunluğu sosyal sermayenin toplamında farklı olarak değerlendirilebilecektir. Örneğin, bağlayıcı sosyal sermayeyi ifade eden yakın çevre ilişkileri kişinin daha geniş toplum kesimleri içerisindeki ilişkilerini olumsuz etkileyebilmektedir.

Sosyal sermayenin ölçümüne ilişkin çalışmalarda göstergelerin çok farklı seçilebilmesi kullanılan veri setlerinin de büyük ölçüde farklılaşmasına neden olmaktadır. Dolayısıyla, ölçüm çalışmalarında kullanılması genel kabul görmüş belirli veriler bulunmaktadır. Mevcut veriler dikkate alındığında, zaman kullanımı araştırmalarında faaliyetlerin nerede, ne kadar süreyle kiminle birlikte yürütüldügü gibi 
detayları içermesi dolayısıyla sosyal sermayenin yapısal boyutu açısından incelenmesini sağlayan geniş kapsamlı bilgi sunduğu görülmektedir. Bu nedenle, Türkiye'de sosyal sermayenin nicel olarak ölçülmesine ilişkin bir çalışmada, zaman kullanımı anketinin kullanılmasının uygun olacağı değerlendirilmektedir. Diğer taraftan, her ne kadar sosyal sermayenin yapısal boyutunun ölçümünde önemli detayların yakalanmasına imkan sağlasa da, zaman kullanımı araştırmaları bilişsel boyutun kavranmasında sınırlı bir kapsama sahiptir. Dolayısıyla, sosyal sermayenin bilişsel boyutunun nitel yöntemle yürütülen bir araştırmayla ölçümü uygun olacaktır. Nicel ve nitel yöntemlerle yapılan incelmelerin birlikte ele alınması sosyal sermayenin her iki boyutu açısından da yeterli düzeyde incelenebilmesine olanak sağlayacaktır. İleriki dönemlerde ise doğrudan bu konuya odaklanan ya da mevcutta yapılmakta olan bir saha araştırmasına eklenen yeni bir bölüm aracılığıyla doğrudan sosyal sermayeye yönelik geniş bilgi sağlayan bir araştırmanın yapılmasının faydalı olacağı düşünülmektedir. 


\section{Annex 1:}

\begin{tabular}{|c|c|c|c|c|c|}
\hline Author & Year & Country & Data Source & Social Capital Dimensions & Method of Analysis \\
\hline \multirow[t]{2}{*}{ Knack \& Keefer } & \multirow[t]{2}{*}{1997} & \multirow{2}{*}{$\begin{array}{|lr|}29 & \text { Market } \\
\text { economies }\end{array}$} & \multirow[t]{2}{*}{ WVS } & Trust & \multirow{2}{*}{$\begin{array}{l}\text { - OLS regression } \\
\text { - } 2 \text { Stage Least Sq. reg. }\end{array}$} \\
\hline & & & & Civic Cooperation & \\
\hline \multirow[t]{2}{*}{ Brehm \& Rahn } & \multirow[t]{2}{*}{1997} & \multirow[t]{2}{*}{ USA } & \multirow[t]{2}{*}{ GSS } & Civic Engagement & \multirow{2}{*}{$\begin{array}{l}\text { Pooled cross-sectional } \\
\text { Structural Model }\end{array}$} \\
\hline & & & & Interpersonal Trust & \\
\hline \multirow[t]{2}{*}{ Paxton } & \multirow[t]{2}{*}{1999} & \multirow[t]{2}{*}{ USA } & \multirow[t]{2}{*}{ GSS, 1975-1994 } & Objective ties (Associations) & \multirow{2}{*}{$\begin{array}{l}\text { - Polychoric correlation matrix } \\
\text { - Max-likelihood estimation model }\end{array}$} \\
\hline & & & & Subjective ties (Trust) & \\
\hline \multirow[t]{2}{*}{ Hall } & \multirow[t]{2}{*}{1999} & \multirow[t]{2}{*}{ UK } & \multirow{2}{*}{$\begin{array}{l}\text { Civic Culture Sur.; Pol. Action Sur.; WVS; } \\
\text { Eurobarometer }\end{array}$} & Networks of sociability & \multirow[t]{2}{*}{ NM } \\
\hline & & & & Norms of social trust & \\
\hline \multirow[t]{5}{*}{ Putnam } & \multirow[t]{5}{*}{2000} & \multirow[t]{5}{*}{ USA } & \multirow{5}{*}{$\begin{array}{l}\text { GSS; Roper Social \& Political Trends Achieve; } \\
\text { DDB Needham Life Style Achieve }\end{array}$} & Community Org. Life & \multirow[t]{5}{*}{ Factor analysis } \\
\hline & & & & Engagement in Public Affairs & \\
\hline & & & & Community Volunteerism & \\
\hline & & & & Informal Sociability & \\
\hline & & & & Social Trust & \\
\hline Glaeser et.al. & 2001 & USA & GSS, 1972-1998 & Organisation membership & $\begin{array}{l}\text { - OLS regression } \\
\text { - } 2 \text { Stage Least Square. regression }\end{array}$ \\
\hline \multirow[t]{7}{*}{ Narayan \& Cassidy } & \multirow[t]{7}{*}{2001} & \multirow{7}{*}{\begin{tabular}{|l|} 
Ghana \\
Uganda
\end{tabular}} & \multirow[t]{7}{*}{ Questionnaire constructed by the researchers } & Group Characteristics & \multirow{7}{*}{$\begin{array}{l}\text { - Exploratory factor analysis (Principle } \\
\text { component analysis \& Non-linear } \\
\text { principal components analysis) } \\
-\quad \text { Confirmatory factor analysis } \\
\text { (Structural equation modelling) }\end{array}$} \\
\hline & & & & Generalized Norms & \\
\hline & & & & Trust & \\
\hline & & & & Togetherness (how well people get along) & \\
\hline & & & & Everyday Sociability & \\
\hline & & & & Neighbourhood Connections & \\
\hline & & & & Volunteerism & \\
\hline \multirow[t]{3}{*}{ Costa \& Kahn } & 2002 & USA & $\begin{array}{l}\text { American Nat. Election St.; Americans' Use of } \\
\text { Time; Current Pop. Sur.; DDB Life Style Sur.; }\end{array}$ & $\begin{array}{l}\text { Outside home SC } \\
\text { Volunteering }\end{array}$ & Probit equation \\
\hline & & & The 5 Nation St.; GSS; Giving \& Volunteering in & Memberships & \\
\hline & & & $\begin{array}{l}\text { US; NPD Group Time Study; Political Part. in } \\
\text { America; Time Use in Eco \& Soc Accounts }\end{array}$ & $\begin{array}{l}\text { Within home SC } \\
\text { Entertaining \&Visiting }\end{array}$ & \\
\hline Stone \& Hughes & 2002 & Australia & Survey data collected within the 'Families, Social & Norms of trust & Pearson's correlation \\
\hline & & & Capital \& Citizenship Project, 2000-2001 & Reciprocity & Principle comp. analysis \\
\hline & & & & Size & Cluster analysis \\
\hline & & & & Network charact.: Density & - Squared Euclidean distance measure, \\
\hline & & & & Network charact.: Diversity & av.met., multivariate reg.1 \\
\hline
\end{tabular}

\section{SAD / JSR}

Cilt / Volume 24 Sayı / Number 3 


\begin{tabular}{|c|c|c|c|c|c|c|}
\hline Author & Year & Country & Data Sc & urce & Social Capital Dimensions & Method of Analysis \\
\hline \multirow{5}{*}{$\begin{array}{|lll|}\text { Grootaert } \quad \& \quad \text { van } \\
\text { Bastelaer }\end{array}$} & \multirow{5}{*}{2002} & \multirow[t]{5}{*}{ Global } & \multirow{2}{*}{$\begin{array}{l}\text { Qual. } \\
\text { analy. }\end{array}$} & Open-ended comm. discuss. & Community profile & \multirow[t]{2}{*}{ NM } \\
\hline & & & & Semi-str.inter.; Key inf.inter; Foc.gr.int & Organisational profile & \\
\hline & & & \multirow{3}{*}{$\begin{array}{l}\text { Quan. } \\
\text { Analy. }\end{array}$} & Struc. Comm. Interv. & Community profile & \multirow{3}{*}{$\begin{array}{l}\text { - Factor analysis/ } \\
\text { component analysis } \\
\text { - Multivariate analysis }\end{array}$} \\
\hline & & & & Household question. & Str.dim. of soc.cap.; Cog.dim. of soc.cap & \\
\hline & & & & Org.nal profile: scoresh. & Organisational profile & \\
\hline \multirow[t]{3}{*}{ Ruston } & \multirow[t]{3}{*}{2003} & \multirow[t]{3}{*}{ UK } & \multirow{3}{*}{\multicolumn{2}{|c|}{ UK 2000 Time Use Survey }} & Formal participation & \multirow{3}{*}{$\begin{array}{l}- \\
- \\
\text { - Logistic regression }\end{array}$} \\
\hline & & & & & Informal involvement & \\
\hline & & & & & Informal sociability & \\
\hline Patulny & \multirow{7}{*}{$\begin{array}{l}2003 \\
2004\end{array}$} & \multirow{7}{*}{$\begin{array}{l}\text { Developing } \\
\text { countries }\end{array}$} & \multirow{7}{*}{\multicolumn{2}{|c|}{$\begin{array}{l}\text { WVS; Australian Use of Time Sur. } \\
\text { Questionnaire constructed by the researchers (SC- } \\
\text { IQ) }\end{array}$}} & Volunteering & \multirow{7}{*}{\begin{tabular}{|l|} 
OLS regression \\
Factor analysis
\end{tabular}} \\
\hline \multirow[t]{6}{*}{ Grootaert et.al. } & & & & & Groups \& Networks & \\
\hline & & & & & \begin{tabular}{|l|} 
Trust \& Solidarity \\
\end{tabular} & \\
\hline & & & & & Collective Action \& Coop. & \\
\hline & & & & & Info. \& Comm. & \\
\hline & & & & & Social Cohesion \& Inclusion & \\
\hline & & & & & Empowerment \& Pol. Action & \\
\hline \multirow[t]{8}{*}{ Bullen \& Onyx } & \multirow[t]{8}{*}{2005} & \multirow[t]{8}{*}{ New South Wales } & \multirow{8}{*}{\multicolumn{2}{|c|}{ Questionnaire constructed by the researchers }} & Participation in local comm. & \multirow[t]{8}{*}{ Factor analysis } \\
\hline & & & & & Neighbourhood connections & \\
\hline & & & & & Work connections & \\
\hline & & & & & Family \& friend connections & \\
\hline & & & & & Proactivity in a soc. context & \\
\hline & & & & & Feelings of trust and safety & \\
\hline & & & & & Tolerance of diversity & \\
\hline & & & & & Value of life & \\
\hline \multirow{2}{*}{\begin{tabular}{|l|l|} 
Beugelsdijk \& van \\
Schaik
\end{tabular}} & \multirow[t]{2}{*}{2005} & \multirow{2}{*}{\begin{tabular}{|l}
54 reg. Fr, It,,UK, \\
Ger,Sp,Nt,Belg. \\
\end{tabular}} & Europe & n Value Survey & Trust & Factor analysis \\
\hline & & & & & Civic engagement & \\
\hline Nyhan-Jones & 2007 & Low income & Qualita & ive research: & Groups \& Networks & NM \\
\hline Woolcock & & countries & - Partici & patory methods & Trust \& Solidarity & \\
\hline & & & - Key-iı & formant interview & Collective Action \& Coop. & \\
\hline & & & - Partici & pant observation & Info. \& Communication & \\
\hline & & & & & Social Cohesion \& Inclusion & \\
\hline & & & & & Empowerment \& Pol. Action & \\
\hline & & & Quantit & tive research: Revised SC-IQ & Groups \& Networks & NM \\
\hline & & & & & Trust \& Solidarity & \\
\hline & & & & & Collective Action \& Coop. & \\
\hline & & & & & Info. \& Communication & \\
\hline & & & & & Social Cohesion \& Inclusion & \\
\hline & & & & & Empowerment \& Pol. Action & \\
\hline
\end{tabular}




\begin{tabular}{|c|c|c|c|c|c|c|}
\hline \multirow{10}{*}{\begin{tabular}{|l|} 
Author \\
Hodgkin \\
\end{tabular}} & \multirow{10}{*}{$\begin{array}{l}\text { Year } \\
2008\end{array}$} & \multirow{10}{*}{$\begin{array}{l}\text { Country } \\
\text { Australia }\end{array}$} & \multirow{7}{*}{$\begin{array}{l}\text { Data Source } \\
\text { Quantitative research: Questionnaire } \\
\text { constructed by the Baum et. al. (2000) }\end{array}$} & \begin{tabular}{|l|} 
Social Capital Dimensions \\
\end{tabular} & \multicolumn{2}{|c|}{ Method of Analysis } \\
\hline & & & & Social participation-informal & \multirow{9}{*}{$\begin{array}{l}\text { Explanatory } \\
\text { sequential } \\
\text { analysis }\end{array}$} & \multirow{6}{*}{$\begin{array}{l}\text { One-way between- } \\
\text { groups multivariate } \\
\text { analysis of variance }\end{array}$} \\
\hline & & & & Social participation-in public spaces & & \\
\hline & & & & \begin{tabular}{|l} 
Social participation-group act. \\
\end{tabular} & & \\
\hline & & & & Civic participation-individual act. & & \\
\hline & & & & Civic participation -collective act. & & \\
\hline & & & & Comm gr. part.-mix of social \&civic & & \\
\hline & & & \multirow{3}{*}{$\begin{array}{l}\text { Qualitative research: } \\
\text { - In-depth interviews } \\
\text { - Diary/Written reflections }\end{array}$} & The range \& types of part. involved in & & \multirow[t]{3}{*}{ Narrative analysis } \\
\hline & & & & Caring active \& their effects & & \\
\hline & & & & Having done smt in a diff. way in life before & & \\
\hline \multirow[t]{3}{*}{ Xue } & \multirow[t]{3}{*}{2008} & \multirow[t]{3}{*}{ Canada } & \multirow{3}{*}{$\begin{array}{l}\text { Longitudinal } \\
\text { of Immigrants to Canada }\end{array}$} & Family \& relatives & \multirow{3}{*}{\multicolumn{2}{|c|}{$\begin{array}{l}\text { Panel data } \\
\text {-fixed-effects } \\
\text {-logit mod., gen.est.eq.pop.-av log mod }\end{array}$}} \\
\hline & & & & \begin{tabular}{|l|} 
Friends \\
\end{tabular} & & \\
\hline & & & & Groups \& organisations & & \\
\hline \multirow[t]{5}{*}{ Sabatini } & \multirow[t]{5}{*}{2009} & \multirow[t]{5}{*}{ Italy } & \multirow{5}{*}{$\begin{array}{l}\text { Indagine multiscopo sulle famiglie (2000- } \\
\text { 2001-2002-2003-2004) }\end{array}$} & Strong family ties & \multirow{5}{*}{\multicolumn{2}{|c|}{$\begin{array}{lcc}\text { - } & \text { Principal components } & \text { analyses } \\
\text { - Structural equations models } & \end{array}$}} \\
\hline & & & & Weak informal ties & & \\
\hline & & & & \begin{tabular}{|l} 
Voluntary organizations \\
\end{tabular} & & \\
\hline & & & & Political participation & & \\
\hline & & & & Civic awareness & & \\
\hline \multirow{10}{*}{$\begin{array}{l}\text { Christoforou } \\
\text { McAloney et.al. }\end{array}$} & 2011 & 14 Euro Countries & European Community Household Panel & Group membership & Binary logist & sression model \\
\hline & \multirow[t]{9}{*}{2011} & \multirow[t]{9}{*}{ Northern Ireland } & \multirow{9}{*}{\begin{tabular}{lrrr}
- & SCQ & \multicolumn{2}{c}{ (Bullen\&Onyx) } \\
- & General $\quad$ Hh & Sur., & 2001 \\
- & Continuous & Hh \\
Sur., & \multicolumn{2}{c}{ 2003\&2004 } \\
- Northern Ireland Hh Panel & Sur, 2011 \\
- Community Attitudes Sur, 2002
\end{tabular}} & Trust and politics & \multirow{9}{*}{\multicolumn{2}{|c|}{$\begin{array}{l}\text { Exploratory and confirmatory factor } \\
\text { analyses }\end{array}$}} \\
\hline & & & & Formal part. in community & & \\
\hline & & & & Work connections & & \\
\hline & & & & Tolerance of diversity & & \\
\hline & & & & Neighbourhood Connection & & \\
\hline & & & & Value of life & & \\
\hline & & & & Family \& friends connection & & \\
\hline & & & & Proactivity & & \\
\hline & & & & Neighbourhood safety & & \\
\hline \multirow{6}{*}{$\begin{array}{l}\text { Van Beuningen \& } \\
\text { Schmeets }\end{array}$} & \multirow[t]{6}{*}{2013} & \multirow[t]{6}{*}{ The Netherlands } & \begin{tabular}{|l} 
- Permanent Survey on Living Conditions \\
\end{tabular} & Social Participation & Structural eq & $\mathrm{n}$ modelling based on \\
\hline & & & 2009 & Organizational Part. & partial least s & es estimations \\
\hline & & & Parliamentary & Political Participation & & \\
\hline & & & Election Study & Social Trust & & \\
\hline & & & & Organizational Trust & & \\
\hline & & & & Political Trust & & \\
\hline Weaver et.al. & 2013 & Canada & General Social Survey & Bonding Social Capital & Multivariate & ysis: Ordinal logistic \\
\hline & & & & Bridging Social Capital & reg. & \\
\hline Addis \& Joxhe & 2016 & Italy & Multiscopo Sur. 1997 \& 2011 & Civic Participation & OLS regress & \\
\hline Hamilton et.al & 2016 & 132 countries & \begin{tabular}{|l} 
Gallup World Poll; ESS; WVS \\
\end{tabular} & Trust & NM & \\
\hline
\end{tabular}




\section{Table 1: Selected Empirical Studies on Social Capital (cont.)}

\begin{tabular}{|c|c|c|c|c|c|}
\hline Author & Year & Country & Data Source & Social Capital Dimensions & Method of Analysis \\
\hline \multirow[t]{2}{*}{$\begin{array}{l}\text { US Congress Joint } \\
\text { Economic } \\
\text { Committee }\end{array}$} & \multirow[t]{2}{*}{2018} & \multirow[t]{2}{*}{ USA } & \multirow{2}{*}{$\begin{array}{l}\text { American Comm. Sur.; Nat. Sur. of Child. } \\
\text { Health; Behavioral Risk Factor Surveillance } \\
\text { System; Civic Engagement Supp. to Nov. } \\
\text { 2008, Pop. Sur.; Volunteer Supp. to } \\
\text { Nov.2013, Pop. Sur.; Volunteer Supp. to } \\
\text { Sep.2015, Pop. Sur.; County Business } \\
\text { Patterns; ACS pop. Estimates; IRS, Business } \\
\text { Master File; ACS population estimates; US } \\
\text { Religion Census; Election Admin. \& Voting } \\
\text { Sur.; Census Bureau; FBI Uniform Crime } \\
\text { Reporting Stat. }\end{array}$} & 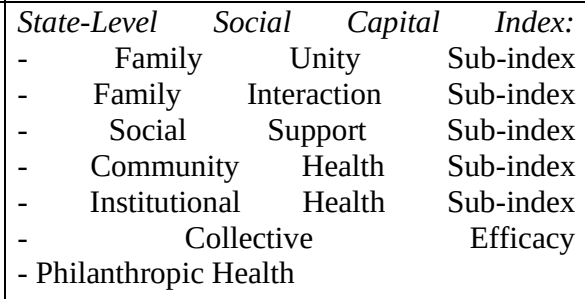 & \multirow[t]{2}{*}{ Principal components analysis } \\
\hline & & & & 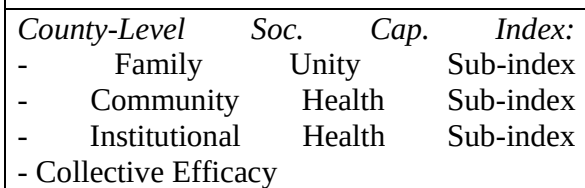 & \\
\hline \multirow[t]{2}{*}{ Wichowsky } & \multirow[t]{2}{*}{2019} & \multirow[t]{2}{*}{ USA } & \multirow[t]{2}{*}{ Current Population Survey, 2008 and 2011} & Group Membership & \multirow[t]{2}{*}{ OLS regression } \\
\hline & & & & Reciprocal Exchange with Neighbours & \\
\hline \multirow{4}{*}{$\begin{array}{l}\text { Office for National } \\
\text { Statistics, UK }\end{array}$} & \multirow[t]{4}{*}{2020} & \multirow[t]{4}{*}{ UK } & \multirow{4}{*}{$\begin{array}{l}\text { Understanding Society: UK Hh Longitudinal } \\
\text { Study; ESS; Community Life Sur.; Opinions } \\
\text { \& Lifestyle Sur.; Electoral Commission; } \\
\text { European Qual. of Life Sur.; Eurobarometer; } \\
\text { Crime Sur. for Eng. \& Wales }\end{array}$} & \begin{tabular}{|l|} 
Personal Relationships \\
\end{tabular} & \multirow[t]{4}{*}{ NM } \\
\hline & & & & \begin{tabular}{|l|} 
Social Network Support \\
\end{tabular} & \\
\hline & & & & Civic engagement & \\
\hline & & & & Trust \& Cooperative Norms & \\
\hline \multirow[t]{3}{*}{ OECD } & \multirow[t]{3}{*}{2020} & \multirow[t]{3}{*}{ OECD Countries } & \multirow{3}{*}{$\begin{array}{l}\text { OECD Survey of Adult Skills; EU SILC; } \\
\text { Gallup World Poll; OECD Ind.s of Reg. Pol. } \\
\text { \& Govern.; OECD Women in Politics; } \\
\text { Transparency Int. Corruption Percept. Index }\end{array}$} & Trust & \multirow[t]{3}{*}{ Spearman correlation } \\
\hline & & & & \begin{tabular}{|l|} 
Volunteering \\
\end{tabular} & \\
\hline & & & & Governance \& Institutional Arrangements & \\
\hline \multirow[t]{5}{*}{ Legatum Institute } & \multirow[t]{5}{*}{2020} & \multirow{5}{*}{$\begin{array}{l}167 \quad \text { countries } \\
\text { across the World }\end{array}$} & \multirow{5}{*}{$\begin{array}{lrrr}- & \text { Gallup } & \text { World } & \text { Poll } \\
- & & \text { IDEA } \\
- & & \text { WEF } \\
\text { - IVS \& } & \text { Bar } & & \end{array}$} & Personal \& Family Relations. & \multirow{5}{*}{$\begin{array}{lc}\text { - } & \text { Cronbach's } \\
\text { - Monte Carlo simulations }\end{array}$} \\
\hline & & & & \begin{tabular}{|l|} 
Social Networks \\
\end{tabular} & \\
\hline & & & & \begin{tabular}{|l|} 
Interpersonal Trust \\
\end{tabular} & \\
\hline & & & & Institutional Trust & \\
\hline & & & & Civic \& Social Participation & \\
\hline
\end{tabular}

Abbreviations: WVS - World Values Survey, OLS - Ordinary Least Squares, GSS - General Social Survey, NM - Not mentioned, SC-IQ - Social Capital Integrated Questionnaire, SCQ - Social Capital Questionnaire, ESS - European Social Survey, IRS - Internal Revenue Service, ACS - American Community Survey, EU SILC - European Union Survey of income and Living Conditions, WEF - World Economic Forum 
Annex 2:

Table 2: Selected Empirical Studies on Social Capital in Turkey

\begin{tabular}{|c|c|c|c|c|c|}
\hline Author & Year & Country / Location & Data Source & Social Capital Dimensions & Method of Analysis \\
\hline Karagül \& Dündar & 2006 & 45 Countries & WVS & Trust & OLS regression \\
\hline \multirow[t]{5}{*}{ Uçar } & \multirow[t]{5}{*}{2016} & \multirow{5}{*}{$\begin{array}{l}\text { Ankara, Hacettepe } \\
\text { and Gazi } \\
\text { (alumiviversity }\end{array}$} & \multirow{5}{*}{$\begin{array}{l}\text { Questionnaire constructed by the } \\
\text { researcher }\end{array}$} & Strategic trust & \multirow{5}{*}{$\begin{array}{l}\text { Factor analysis } \\
\text { (Cronbach's alpha for reliability) }\end{array}$} \\
\hline & & & & Generalized trust & \\
\hline & & & & Institutional trust & \\
\hline & & & & Common values & \\
\hline & & & & Group belonging & \\
\hline \multirow[t]{4}{*}{ Eşki-Uğuz et. al. } & \multirow[t]{4}{*}{2011} & \multirow[t]{4}{*}{ Turkey } & \multirow{4}{*}{$\begin{array}{l}\text { Questionnaire constructed by the } \\
\text { researchers }\end{array}$} & Civic and political activism & \multirow[t]{4}{*}{ Frequency analysis } \\
\hline & & & & Feelings of trust and safety & \\
\hline & & & & Tolerance & \\
\hline & & & & Neighbourhood & \\
\hline \multirow[t]{3}{*}{ Özdemir } & \multirow[t]{3}{*}{2008} & \multirow{3}{*}{$\begin{array}{l}\text { Uni. in Tr. with } \\
\text { highest number of } \\
\text { publishing }\end{array}$} & \multirow{3}{*}{$\begin{array}{l}\text { Questionnaire constructed on the scales } \\
\text { designed by Hansen (1999), Johnson } \\
\text { (1996) and McAllister (1995) }\end{array}$} & Networks & \multirow{3}{*}{$\begin{array}{l}\text { - Principal components analysis } \\
\text { - Hierarchical regression }\end{array}$} \\
\hline & & & & Trust based on altruism & \\
\hline & & & & Trust based on competence & \\
\hline \multirow[t]{8}{*}{ Ardahan } & \multirow[t]{8}{*}{2012} & \multirow[t]{8}{*}{ Antalya } & \multirow{8}{*}{\begin{tabular}{|lll} 
Questionnaire constructed by Onyx \& \\
Bullen (2000)
\end{tabular}} & Participation in local communities & \multirow{8}{*}{$\begin{array}{l}\text { Exploratory factor analysis } \\
\text { (Cronbach's alpha for reliability) }\end{array}$} \\
\hline & & & & Neighbourhood relation & \\
\hline & & & & Belonging & \\
\hline & & & & Tolerance of diversity & \\
\hline & & & & Membership to civil society organisations & \\
\hline & & & & Trust in the people in the community & \\
\hline & & & & Trust in the living area & \\
\hline & & & & Social roles \& responsibility & \\
\hline \multirow[t]{6}{*}{ Tatlı } & \multirow[t]{6}{*}{2013} & \multirow{6}{*}{$\begin{array}{l}\text { Malatya, Elazı̆̆, } \\
\text { Bingöl, Tunceli }\end{array}$} & \multirow{6}{*}{$\begin{array}{l}\text { Questionnaire constructed by the } \\
\text { researchers }\end{array}$} & Groups and networks & \multirow{6}{*}{$\begin{array}{l}\text { Logit model } \\
\text { - Maximum likelihood estimation }\end{array}$} \\
\hline & & & & Trust and solidarity & \\
\hline & & & & Collective action and coop. & \\
\hline & & & & Information and communication & \\
\hline & & & & Social cohesion & \\
\hline & & & & Empowerment \& pol. Action & \\
\hline Akın \& Aytun & 2014 & 41 countr.(exc.Tr.) & World Bank database & Communication & Panel causality analysis \\
\hline \multirow[t]{3}{*}{ Çalışkan et.al. } & \multirow[t]{3}{*}{2014} & \multirow[t]{3}{*}{ Yalova } & \multirow{3}{*}{$\begin{array}{l}\text { Questionnaire constructed by the } \\
\text { researchers based on SOCAT and Çalışkan } \\
\text { \& Meçik (2011) }\end{array}$} & Trust & \multirow{3}{*}{$\begin{array}{l}\text { Social capital index } \\
\text { Semi-logarithmic model }\end{array}$} \\
\hline & & & & Norms & \\
\hline & & & & Networks & \\
\hline
\end{tabular}




\begin{tabular}{|c|c|c|c|c|c|}
\hline \begin{tabular}{|l|} 
Author \\
\end{tabular} & Year & Country / Location & \begin{tabular}{|l|} 
Data Source \\
\end{tabular} & Social Capital Dimensions & Method of Analysis \\
\hline Keleş et.al. & 2015 & Erzurum (rural area) & $\begin{array}{l}\text { Questionnaire constructed by the } \\
\text { researchers based on Narayan \& } \\
\text { Cassidy (2001) and Onyx \& Bullen } \\
(2000)\end{array}$ & $\begin{array}{l}\text { Structural social capital } \\
\text { - social relations } \\
\text { Relational social capital } \\
\text { - trust, trustworthiness, norms \& sanctions, } \\
\text { recip.Cognitive social capital } \\
\text { - behavioural norms, common values, } \\
\text { recipr.\&trust }\end{array}$ & Structural equation model \\
\hline Erbaş1 & 2015 & $\begin{array}{l}37 \text { districts in Konya \& } \\
\text { Karaman }\end{array}$ & \begin{tabular}{|l|} 
Turkstat and \\
Registration data \\
\end{tabular} & $\begin{array}{l}18 \text { indicators related to socio-economic, } \\
\text { demographic, cultural issues and civic part. }\end{array}$ & Principle components analysis \\
\hline \multirow[t]{6}{*}{ Özpınar et.al. } & \multirow[t]{6}{*}{2016} & \multirow[t]{6}{*}{ İstanbul, Ankara, İzmir } & \multirow{6}{*}{$\begin{array}{l}\text { Questionnaire constructed by the } \\
\text { researchers }\end{array}$} & Organisation membership & \multirow[t]{6}{*}{ Descriptive analysis } \\
\hline & & & & Political activity & \\
\hline & & & & Social networks & \\
\hline & & & & Participation in cultural activities & \\
\hline & & & & \begin{tabular}{|l|} 
Daily life practices \\
\end{tabular} & \\
\hline & & & & Consumption patterns & \\
\hline \multirow[t]{8}{*}{ Kizilkaya } & \multirow[t]{8}{*}{2017} & \multirow[t]{8}{*}{ Turkey } & \multirow[t]{8}{*}{ International Country Risk Guide } & Contract viability & \multirow{8}{*}{$\begin{array}{l}\text { - Principal components analysis } \\
\text { - Structural break cointegration test } \\
\text { - DOLS estimation method }\end{array}$} \\
\hline & & & & Law and order & \\
\hline & & & & Economic risk assessment & \\
\hline & & & & Financial risk assessment & \\
\hline & & & & Political risk assessment & \\
\hline & & & & Democratic accountability & \\
\hline & & & & Government stability & \\
\hline & & & & Legislative power & \\
\hline Vergil \& Bahtiyar & 2017 & 28 EU countr.\& Tr & WVS; European Val. Sur.; Eurobarom & Trust & - Panel data analysis \\
\hline Kartal et.al. & 2017 & $\begin{array}{l}\text { Çanakkale } 18 \text { Mart Uni., } \\
\text { Fac. of Edu. \& Erzurum } \\
\text { Atatürk Uni.Fac. of Edu. }\end{array}$ & $\begin{array}{l}\text { Questionnaire constructed by Onyx \& } \\
\text { Bullen (2000) }\end{array}$ & NM & Ordinal logistic regression analysis \\
\hline Öztopçu & 2018 & Turkey (across regions) & Turkstat database & $\begin{array}{l}\text { - Divorce rate } \\
\text { - Voter turnout } \\
\text { - Migration } \\
\text { - Number of university graduates } \\
\text { - Number of suicides } \\
\text { - Number of theatres }\end{array}$ & - Principal components analysis \\
\hline
\end{tabular}




\begin{tabular}{|c|c|c|c|c|c|}
\hline Author & Year & Country / Location & Data Source & Social Capital Dimensions & Method of Analysis \\
\hline Baş & 2018 & $\begin{array}{l}\text { Selected Uni.s in } \\
\text { Turkey }\end{array}$ & $\begin{array}{lll}\text { Questionnaire } & \text { constructed } & \text { by } \\
\text { William (2006) } & & \end{array}$ & $\begin{array}{l}\text { Bridging social capital: } \\
\text { - Outward looking } \\
\text { - Contact with a broad range of people } \\
\text { - View of oneself as part of a broader group } \\
\text { - Diffuse reciprocity with a broader community } \\
\text { Bonding social capital: } \\
\text { - Emotional support } \\
\text { - Access to scarce or limited resources } \\
\text { - Ability to mobilize solidarity } \\
\text { - Out group antagonism }\end{array}$ & Structural equation modelling \\
\hline Polatcan & 2018 & $\begin{array}{l}\text { Ankara (Schools in } \\
\text { Yenimahalle district) }\end{array}$ & $\begin{array}{l}\text { Questionnaire constructed by the } \\
\text { researcher }\end{array}$ & \begin{tabular}{|l} 
Loyalty \\
Social interaction bonds \\
Trust \\
Participation \\
Cultural memory
\end{tabular} & \begin{tabular}{|l} 
Factor analysis \\
(Cronbach's alpha for reliability)
\end{tabular} \\
\hline Türkseven \& Kutlar & 2019 & $\begin{array}{ll}\text { Kırıkkale, } & \text { Aksaray, } \\
\text { Kırşehir, } & \text { Nevşehir } \\
\text { and Niğde } & \end{array}$ & Turkstat and Registration data & \begin{tabular}{|l|} 
Number of active associations \\
Number of courses \\
Number of enterprises \\
Number of marriages \\
Number of divorces \\
\end{tabular} & $\begin{array}{l}\text { Panel data analysis } \\
\text { - Seemingly unrelated regression model }\end{array}$ \\
\hline Seki & 2019 & $\begin{array}{l}\text { Çanakkale } 18 \text { Mart } \\
\text { Uni., Fac. of Eco. \& } \\
\text { Adm.Scie }\end{array}$ & $\begin{array}{l}\text { Questionnaire constructed by the } \\
\text { researcher }\end{array}$ & \begin{tabular}{|l|} 
Trust \\
Networks \\
Reciprocal assistance and cooperation \\
\end{tabular} & Frequency analysis \\
\hline Kuştepeli et.al. & 2019 & $\begin{array}{l}\text { Info. \& comm. tech. } \\
\text { sector in Tr\&Germ. }\end{array}$ & European Comm. CORDIS website & Linking social capital (collab. betw. academics) & Social network analysis \\
\hline Paksoy \& Gül & 2019 & $\begin{array}{l}\text { Gaziantep Uni., Fac. } \\
\text { of Eco. \& Adm. Sci. }\end{array}$ & $\begin{array}{l}\text { Questionnaire constructed by the } \\
\text { researchers based on the Social } \\
\text { Capital Index const. by Uçar (2016) }\end{array}$ & \begin{tabular}{|l|} 
Strategic trust \\
Generalized trust \\
Institutional trust \\
Common values \\
Group belonging \\
\end{tabular} & $\begin{array}{l}\text { Factor analysis } \\
\text { (Cronbach's alpha for reliability) } \\
\text { T-Test } \\
\text { ANOVA }\end{array}$ \\
\hline Şentuna \& Çak1 & 2020 & Balıkesir & $\begin{array}{l}\text { Questionnaire constructed by the } \\
\text { researchers }\end{array}$ & $\begin{array}{l}\text { Neighbourhood capital } \\
\text { Civil society capital } \\
\text { Family capital } \\
\text { Neighbour capital } \\
\text { Finance capital } \\
\text { Trust capital } \\
\text { Party capital }\end{array}$ & \begin{tabular}{|l} 
Explanatory factor analysis \\
(Cronbach's alpha for reliability)
\end{tabular} \\
\hline
\end{tabular}




\section{KAYNAKÇA}

Aaltio, I., Kyrö, P. and Sundin, E. (2008). Women Entrepreneurship and Social Capital A Dialogue and Construction. Copenhagen Business School Press.

Addis, E. and Joxhe, M. (2016). Gender Gaps in Social Capital: A Theoretical Interpretation of the Italian Evidence. Dipartimento di Scienze Sociali ed Economiche, Working Paper Series No.2/2016.

Afanasev, D.V., Guzhavina, T.A. and Mekhova, A.A. (2016). Social Capital in a Region: Revisiting the Measurement and Building of an Indicator Model. Economic and Social Changes: Facts, Trends, Forecast, Vol.6, No.48, pp. 110-125.

Akın, C.S. and Aytun, C. (2014). Sosyal Sermayenin İşgücü Piyasası Üzerine Etkileri: Panel Nedensellik Analizi. Eskişehir Osmangazi Üniversitesi İIBF Dergisi, Cilt: 9, Sayl: 2, s. 65-80.

Ardahan, F. (2012). Sosyal Sermaye Ölçeği Geçerlilik, Güvenirlilik Çalışması. International Journal of Human Sciences [Online]. Vol. 9, No. 2, pp. 773-789.

Ardahan, F. and Ezici, M.N. (2014). İlköğretim İkinci Kademe Öğrencileri Sosyal Sermaye Ölçeği Adaptasyon Çalışması. Sakarya University Journal of Education. Vol.4, No.3, pp. 6-17.

Arrow, K. J. (2000). Observations on Social Capital. In Dasgupta, P. and Serageldin, I. (2000) Social Capital: A Multifaceted Perspective. Washington D.C.: World Bank.

Aydemir, M.A. (2011). Toplumsal İlişkilerin Sosyal Sermaye Değeri (Topluluk Duygusu ve Sosyal Sermaye Üzerine Bir Araştırma). Doktora Tezi.

Babacan, M.E. (2012). Toplumsal Paylaşım Ağlarında Sosyal Sermaye Pratikleri. Doktora Tezi.

Bahtiyar, B. (2017). Sosyal Sermaye Faktörünün Ekonomik Büyüme Üzerindeki Etkisinin Karşılaştırmalı Analizi. Doktora Tezi.

Basut, Ö. (2020). Sosyal Sermayenin Kalkınma Üzerine Etkisi: Kars İli Üzerine Araştırma. Yüksek Lisans Tezi.

Baş, F.C. (2018). Sosyal Medya Davranışının Oluşumu: Çevrimiçi Ortamlarda Güven, Sosyal Sermaye ve Saygınlık İlişkisi. Sosyoloji Araştırmaları Dergisi, Cilt 21, Sayı 2, s. 49-85.

Beugelsdijk, S. and van Schaik, T. (2005). Differences in Social Capital Between 54 Western European Regions. Regional Studies, Vol. 39, No. 8, pp. 1053-1064. 
Beyer, B.A. (2003). Feminist Consciousness and Social Capital: Bonds, Breaks, and Bridges. Master's Thesis. Illinois.

Boarini, R., Kolev, A. and McGregor, A. (2014). Measuring Well-being and Progress in Countries at Different Stages of Development: Towards a More Universal Conceptual Framework. (2014) OECD Development Centre Working Paper No. 325.

Bourdieu, P. (1986). The Forms of Capital. In J. Richardson (Ed.), Handbook of Theory and Research for the Sociology of Education (pp. 241-258). New York: Greenwood.

Brehm, J. and Rahn, W. (1997). Individual-Level Evidence for the Causes and Consequences of Social Capital. American Journal of Political Science, Vol. 41, No. 3, pp. 999-1023.

Bullen, P. and Onyx, J. (2005). Measuring Social Capital in Five Communities in NSW: A Practitioner's Guide (2nd ed.). Coogee, NSW: Management Alternatives.

Burt, R.S. (1997). The Contingent Value of Social Capital. Administrative Science Quarterly, Vol. 42, No. 2, pp. 339-365.

Byoun, S.J. (2013). The Impact of Human Capital and Social Capital on Employment Conditions of Immigrants in the United States: An Examination of Gender and Racial/Ethnic Differences. PhD Dissertation. Urbana, Illinois.

Calvo, R., Zheng, Y., Kumar, S., Olgiati, A. and Berkman, L. (2012). Well-Being and Social Capital on Planet Earth: Cross-National Evidence from 142 Countries. PLoS ONE, Vol. 7, No. 8, e42793.

Christoforou, A. (2011) Social Capital Across European Countries: Individual and Aggregate Determinants of Group Membership. The American Journal of Economics and Sociology, Vol. 70, No. 3, pp. 699-728.

Coleman, J. S. (1988) Social Capital in the Creation of Human Capital. The American Journal of Sociology, Vol. 94, pp. S95- S120.

Collier, P. (1998). Social Capital and Poverty. Social Capital Initiative Working Paper No. 4. Washington, DC: World Bank.

Costa, D.L. and Kahn, M.E. (2002). Understanding the American Decline in Social Capital, 1952-1998. Kyklos 56(1), 17-46. 
Çalışkan, Ş., Pehlivanoğlu, F. and Meçik, O. (2014). Bireysel Kazançların Belirlenmesinde Sosyal Sermayenin Rolü (Yalova Örneği). Cumhuriyet Üniversitesi İktisadi ve İdari Bilimler Dergisi, Cilt 15, Sayı 1, s. 313-323.

Çıpa,D. (2020). Duygusal ve Kültürel Zekâ, Sosyal Sermaye, İş Doyumu ve Örgütsel Bağlılık İlişkileri: Eğitim Sektöründe Bir Çalışma. Doktora Tezi.

Dasgupta, P. (2000). Economic Progress and the Idea of Social Capital, In Dasgupta, P. and Serageldin, I. (2000) Social Capital: A Multifaceted Perspective. Washington D.C.: World Bank.

Demir, S. A. (2011). Aile ve Sosyal Sermaye İlişkisi. e-Journal of New World Sciences Academy, Vol. 6, No 4, pp. 897-915.

Dewey, J. (1915). The Psychology of the Elementary Curriculum. Chapter 4 in The School and Society. Chicago: University of Chicago.

Durlauf, S. N. (1999). The Case "Against" Social Capital. Focus, Vol. 20, No. 3, University of Wisconsin-Madison Institute for Research on Poverty.

Durlauf, S. N. (2002). On the Empirics of Social Capital. The Economic Journal, Vol. 112, No. 483, pp. 459-479.

Düzgün, A. N. (2018). Türkiye'deki Suriyeli Göçmen Kadınların Savaş Öncesi ve Sonrası Sahip Oldukları Sosyal Sermaye Değişiminin Araştırılması. Yüksek Lisans Tezi.

Erbaş1, A. (2015). İlçeler Düzeyinde Sosyal Sermaye Analizi: Konya ve Karaman Örneği. Sosyoekonomi, Vol. 23, No. 25, pp. 47-78.

Erdoğan, E. (2006). Sosyal Sermaye, Güven ve Türk Gençliği. Available at: http://www.urbanhobbit.net/PDF/Sosyal\%20Sermaye_emre\%20erdogan.pdf Accessed on: 22/05/2021.

Eşki, H. (2009). Sosyal Sermaye - Önemi, Üretimi ve Ölçümü- Üzerine Bir Alan Araştırması. Doktora Tezi.

Eşki-Uğuz, H., Örselli, E. and Sipahi, E.B. (2011). Sosyal Sermayenin Ölçümü: Türkiye Deneyimi. Akademik Incelemeler Dergisi, Cilt 6, Sayı 1, s. 8-40.

Farr, J. (2004). Social Capital: A Conceptual History. Political Theory, Vol.32, No.1, pp. 6-33. 
Fine, B. (2010). Theories of Social Capital: Researchers Behaving Badly. London, New York: Pluto Press.

Fukuyama, F. (2002). Social Capital and Development: The Coming Agenda. SAIS Review, Vol. 22, No. 1, pp. 23-37.

Gabrielson, T. (2006). Woman-Thought, Social Capital, and the Generative State: Mary Austin and the Integrative Civic Ideal in Progressive Thought. American Journal of Political Science, Vol. 50, No. 3, pp. 650-663.

Garcia-Diez, S. (2013). Measurement of Social Capital with the Help of Time Use Surveys. Procedia Social and Behavioral Sciences. Vol. 72, pp. 23-31.

Glaeser, E.L., Laibson, D. and Sacerdote, B. (2001). The Economic Approach to Social Capital. Harvard Institute of Economic Research Working Papers No. 1916.

Granovetter, M. (1973). The Strength of Weak Ties. The American Journal of Sociology, Vol. 78, No. 6, pp. 1360-1380.

Gray, A. (2003). Towards a Conceptual Framework for Studying Time and Social Capital. Families and Social Capital ESRC Research Group Working Paper No.3. London: South Bank University.

Grootaert, C. and van Bastelaer, T. (2001). Understanding and Measuring Social Capital: A Synthesis of Findings and Recommendations from the Social Capital Initiative. Social Capital Initiative Working Paper Series No. 24. Washington, DC: The World Bank.

(2002) Understanding and Measuring Social Capital: A Multidisciplinary Tool for Practitioners. Washington DC: The World Bank.

Grootaert, C., Narayan, D., Nyhan-Jones, V. and Woolcock, M. (2004). Measuring Social Capital: An Integrated Questionnaire. World Bank Working Paper No. 18. Washington, DC: The World Bank.

Halıc1-Tülüce,N.S. (2013). Sosyal Sermaye Faktörünün Ekonomik Büyüme Üzerindeki Etkisi: Dinamik Panel Uygulamas1. Doktora Tezi.

Hall, P.A. (1999). Social Capital in Britain. British Journal of Political Science, 29(3), 417-461.

Hamilton, K., Helliwell, J.F. and Woolcock, M. (2016). Social Capital, Trust and Well-Being in the Evaluation of Wealth. National Bureau of Economic Research Working Paper 22556. 
Hanifan L.J. (1916). The Rural School Community Center. The Annals of the American Academy of Political and Social Science, Vol. 67, pp. 130-138.

Healy, T., Côté, S., Helliwell, J. F, Field, S., Centre for Educational Research Innovation, and OECD (2001). The Well-being of Nations: The Role of Human and Social Capital. Paris: OECD.

Hodgkin, S. (2008). Telling It All: A Story of Women's Social Capital Using a Mixed Methods Approach. Journal of Mixed Methods Research, Vol. 2, No. 4, pp. 296-326.

Huebler, J. (2020). Philanthropy Described in "Democracy in America" by de Tocqueville. Available at: Philanthropy Described in "Democracy in America" by de Tocqueville | Learning to Give Accessed on: 03/02/2020.

Ihlen, O. (2005). The Power of Social Capital: Adapting Bourdieu to the Study of Public Relations. Public Relations Review, 31, pp. 492-496.

Karagül, M. and Dündar, S. (2006). Sosyal Sermaye ve Belirleyicileri Üzerine Ampirik Bir Çalışma. Akdeniz I.I.B.F. Dergisi, Sayı 12, s. 61-78.

Kartal, O.Y., Yazgan, A.D., and Kıncal, R.Y. (2017). Bilişim Çağında Sosyal Sermayenin Yeni Belirleyicileri: Dijital Uçurum ve Sosyal Medya Okuryazarlığı. Ahi Evran Üniversitesi Kırşehir Eğitim Fakültesi Dergisi, Cilt 18, Sayı 2, s. 353-373.

Keeley, B. and OECD (2007). Human Capital: How What You Know Shapes Your Life. Paris: OECD.

Keleş, Ş. (2014). Kırsal Alanda Sosyal Sermayenin Oluşumu Üzerine Bir Araştırma: Erzurum İli Örneği. Doktora Tezi.

Keleş, Ş., Dilmaç, M. and Tural-Dikmen, A. (2015). Sosyal Sermayenin Kırsal Alanda Yaşama İsteği Üzerinde Etkisi: Erzurum Kırsal Alanında Bir Araştırma. The International New Issues in Social Sciences, Vol. 1, No. 1, pp. 91-116.

Kızılkaya (2017). Sosyal Sermayenin Ekonomik Büyüme Üzerindeki Potansiyel Etkisi: Türkiye için Yapısal Kırılmalı Eşbütünleşme Analizi. Sosyoekonomi, Vol. 25, No. 33, pp. 175-194.

Knack S. and Keefer, P. (1997). Does Social Capital Have an Economic Pay-Off? A Cross Country Investigation. Quarterly Journal of Economics, No. 112, pp. 1251-1288.

Kösemen, İ.B. (2010). Sosyal Sermaye Kuramı Çerçevesinde Türkiye'de Özel Sektörün Kültür ve Sanat Yatırımları. Doktora Tezi. 
Krishna, A. and Uphoff, N. (1999). A Conceptual and Empirical Study of Collective Action For Conserving and Developing Watersheds in Rajasthan, India. Social Capital Initiative Working Paper Series No. 13. Washington, DC: The World Bank.

Kuştepeli, Y., Akgüngör, S. and Gülcan, Y. (2019). Social Capital and Turkish-German Academic Linkages. Sosyoekonomi, Vol. 27, No. 39, pp. 205-222.

Legatum Institute (2007). The 2007 Legatum Prosperity Index: A Global Assessment of Wealth and Wellbeing. Dubai: Legatum.

(2008). The 2008 Legatum Prosperity Index: An Inquiry into Global Wealth and Wellbeing. Available at: https://www.prosperity.com/download_file/view_inline/2856 Accessed on: 09/05/2021.

(2009). The 2009 Legatum Prosperity Index: An Inquiry into Global Wealth and Wellbeing. Available at: https://www.prosperity.com/download_file/view_inline/2829 Accessed on: 09/05/2021.

(2010). The 2010 Legatum Prosperity Index: An Inquiry into Global Wealth and Wellbeing. Available at: https://www.prosperity.com/download_file/view_inline/2849 Accessed on: 09/05/2021.

(2011). The 2011 Legatum Prosperity Index: An Inquiry into Global Wealth and Wellbeing. Available at: https://www.prosperity.com/download_file/view_inline/2852 Accessed on: 09/05/2021.

(2012). A Unique Global Inquiry into Wealth and Wellbeing: The 2012 Legatum Prosperity Index. Available at: https://www.prosperity.com/download_file/view_inline/2837 Accessed on: 09/05/2021.

(2013). The Legatum Prosperity Index. Available at: https://www.prosperity.com/download_file/view_inline/2834 Accessed on: 09/05/2021.

(2014). The 2014 Legatum Prosperity Index. Available at: https://www.prosperity.com/download_file/view_inline/2830 Accessed on: 09/05/2021.

(2015). The Legatum Prosperity Index. Available at: https://www.prosperity.com/download_file/view_inline/2833 Accessed on: 09/05/2021.

(2016). The Legatum Prosperity Index, 2016: Bringing Prosperity to Life. Available at: https://www.prosperity.com/download_file/view_inline/2884 Accessed on: 09/05/2021. 
(2017). The Legatum Prosperity Index, 2017. Available at: https://www.prosperity.com/download_file/view_inline/3479 Accessed on: 09/05/2021. (2018). The Legatum Prosperity Index, 2018. Available at: https://www.prosperity.com/download_file/view_inline/3553 Accessed on: 09/05/2021. (2019). The Legatum Prosperity Index: A Tool for Transformation, 2019. Available at: https://www.prosperity.com/download_file/view_inline/3924 Accessed on: 09/05/2021.

(2020). The Legatum Prosperity Index: A Tool for Transformation, 2020. Available at: https://docs.prosperity.com/2916/0568/0539/The_Legatum_Prosperity_Index_2020.pdf Accessed on: 09/05/2021.

Lin (1999). Building a Network Theory of Social Capital'. Connections, Vol.22, No.1, pp. 28-51.

Loury, G.C. (1977). A Dynamic Theory of Racial Income Differences. In Women, Minorities, and Employment Discrimination, In Wallace, P.A., LaMond, A.M. and Massachusetts Institute of Technology, Industrial Relations Section. Women, Minorities, And Employment Discrimination. Lexington, Mass: Lexington Books.

Lowndes, V. (2000). Women and Social Capital: A Comment on Hall's 'Social Capital in Britain'. British Journal of Political Science, Vol. 30, No. 3, pp. 533-537.

McAloney, K. Stringer, M. and Mallett, J. (2011). Social Capital in Divided Societies: Development of a Social Capital Questionnaire in Northern Ireland. International Journal of Social Inquiry, Vol. 4, No. 1, pp. 113-131.

Molyneux, M. (2002). Gender and the Silences of Social Capital: Lessons from Latin America. Development and Change, Vo. 33, No. 2, pp. 167-188.

Narayan, D. and Cassidy, M. F. (2001). A Dimensional Approach to Measuring Social Capital: Development and Validation of a Social Capital Inventory. Current Sociology, Vol. 49, No. 2, pp. 59-102.

Nyhan-Jones, V and Woolcock, M (2007). Using Mixed Methods to Assess Social Capital in Low Income Countries: A Practical Guide. BWPI Working Paper 12. Manchester: Brooks World Poverty Institute, University of Manchester.

OECD (2010). Social Capital, Human Capital and Health: What is the Evidence?. OECD Publishing, Paris. 
(2011). How's Life? Measuring Well-Being, OECD Publishing. https://doi.org/10.1787/9870c393-en

(2013). How's Life? 2013: Measuring Well-Being, OECD Publishing. https://doi.org/10.1787/9789264201392-en

(2015). How's Life? 2015: Measuring Well-Being, OECD Publishing. https://doi.org/10.1787/how_life-2015-en

(2017). How's Life? 2017: Measuring Well-being. OECD Publishing, Paris, https://doi.org/10.1787/how_life-2017-en

(2020). How's Life? 2020: Measuring Well-being. OECD Publishing, Paris, https://doi.org/10.1787/9870c393-en

Office for National Statistics (2020). Social capital in the UK: 2020. Statistical Bulletin.

Olson, M. (1965). The Logic of Collective Action: Public Goods and the Theory of Groups. Harvard University Press.

Özcan, B. (2011). Sosyal Sermaye ve Ekonomik Kalkınma. Doktora Tezi.

Özdemir, A.A. (2008). Sosyal Ağ Özellikleri Bakış Açısıyla Sosyal Sermaye ve Bilgi Yaratma İlişkisi: Akademisyenler Üzerinde Yapılan Bir Alan Araştırması. Anadolu Üniversitesi Sosyal Bilimler Dergisi, Cilt 8, Sayı 2, s. 81-102.

Özpınar, Ş., Özpınar, Ö., Çondur, F. and İkizoğlu, M. (2016). Türkiye'de Üç Büyük Kentte Sosyal Sermayenin Bourdieu'nün Kavramsallaştırması Çerçevesinde Değerlendirilmesi. Dokuz Eylül Üniversitesi İktisadi ve İdari Bilimler Fakültesi Dergisi, Cilt 31, Sayı 1, s. 167-199.

Öztopçu, A. (2018). Bölgesel Sosyal Sermaye ve Bölgesel Gelişmişlik Düzeyinin Kalkınma Üzerindeki Etkileri. Verimlilik Dergisi, Sayı 3, s. 89-113.

Paksoy, H.M. and Gül, M. (2019). Sosyal Sermaye Üzerine Bir Araştırma. International Journal of Disciplines Economics and Administrative Sciences Studies, Vol. 5, No. 13, pp. 321-332.

Pantoja, E. (2002). Qualitative Analysis of Social Capital: The Case of Community Development in Coal Mining Areas in Orissa, India. In Grootaert, C. and van Bastelaer, T. (2002) Understanding and Measuring Social Capital: A Multidisciplinary Tool for Practitioner. Washington D.C.: The World Bank. 
Patulny, R. (2003). Social Capital - Values and Time Use. Paper presented at the 8th Australian Institute of Family Studies Conference, Melbourne.

Paxton, P. (1999). Is Social Capital Declining in the United States? A Multiple Indicator Assessment. American Journal of Sociology, Vol.105, No.1, pp. 88-127.

Polatcan, M. (2018). Okullarda Sosyal Sermaye Ölçeği: Bir Ölçek Geliştirme Çalışması. Uluslararası Türkçe Edebiyat Kültür Eğitim Dergisi, Cilt 7, Sayı 4, s. 2721-2732.

Portes, A. (1998). Social Capital: Social Capital: Its Origins and Applications in Modern Sociology. Annual Review of Sociology, Vol. 24, pp. 1-24.

Prakash, S. (2002). Social Capital and the Rural Poor: What Can Civil Actors and Policies Do? In UNESCO (2002) Social Capital and Poverty Reduction. Paris.

Putnam, R.D. (2000). Bowling Alone: The Collapse and Revival of American Community. Touchstone: New York.

(2001). Social Capital: Measurement and Consequences. Isuma: Canadian Journal of Policy Research, 2, pp. 41-51.

Putnam, R., Leonardi, R. and Nanetti, R.Y. (1993). Making Democracy Work: Civic Traditions in Modern Italy. Princeton, New Jersey:Princeton University Press.

Reid, C. and Salmen L. (2002). Qualitative Analysis of Social Capital: The Case of Agricultural Extension in Mali, In Grootaert, C. and van Bastelaer, T. (2002) Understanding and Measuring Social Capital: A Multidisciplinary Tool for Practitioner. Washington D.C.:The World Bank.

Ruston, D. (2003). Volunteers, Helpers and Socialisers: Social Capital and Time Use. Office for National Statistics, London.

Sabatini, F. (2009). Social Capital as Social Networks: A New Framework for Measurement and an Empirical Analysis of its Determinants and Consequences. The Journal of Socio-Economics, Vol. 38, pp. 429-442.

Schuller, T. (2001). The Complementary Roles of Human and Social Capital. Available at: https://www.oecd.org/innovation/research/1825424.pdf Accessed on: 24/04/2021.

Seki, İ. (2019). Yaratıcı Ekonomi Yaklaşımı Çerçevesinde Üniversite Öğrencilerinin Sosyal Sermaye Seviyesinin Belirlenmesine Yönelik Bir Analiz. Ekonomi Bilimleri Dergisi, Cilt 11, Sayı 1, s. 51-63. 
Serageldin, I. and Grootaert, C. (2000). Defining Social Capital: An Integrating View, In Dasgupta, P. and Serageldin, I. (2000) Social Capital: A Multifaceted Perspective. Washington D.C.: World Bank.

Smart, A. (1993). Gifts, Bribes and Guanxi: A Reconsideration of Bourdieu's Social Capital. Cultural Anthropology, Vol. 8, No. 3, pp. 388-408.

Solow, R. M. (2000). Notes on Social Capital and Economic Performance. In Dasgupta, P. and Serageldin, I. (2000) Social Capital: A Multifaceted Perspective. Washington D.C.: World Bank.

Söylemez, M. and Tolon, M. (2019). Dönüşümsel Liderliğin Sosyal Sermayeye Etkisinde Lider-Üye Etkileşiminin Aracılık Rolü. İşletme Araştırmaları Dergisi, Cilt 11, Sayı 1, s. 372-389.

Stalker, G.J. (2008). Measuring Diversity in Daily Social Contact: The Contribution of Social Context, Work and Leisure on the Opportunity for Engagement. Social Indicators Research, Vol. 86, No. 2, pp. 275-295.

Stone, W. and Hughes, J. (2002a). Social Capital: Empirical Meaning and Measurement Validity. Australian Institute of Family Studies.

(2002b) .Measuring Social Capital: Towards a Standardised Approach. Paper presented at the 2002 Australasian Evaluation Society International.

Sümer, G. (2019). Türkiye'de Lisansüstü Eğitime Devam Eden Suriyeli Kadınların Sosyal Uyumuna Toplumsal Cinsiyet ve Sosyal Sermaye Merkezli Bir Bakış. Yüksek Lisans Tezi.

Şan, M.K. and R. Şimşek (2011). Sosyal Sermaye Kavramının Tarihsel - Sosyolojik Arkaplanı. Akademik Incelemeler Dergisi, Cilt 6, Sayı 6, s. 88-110.

Şentuna, B. and Çakı, F. (2020). Balıkesir Örnekleminde Bir Ölçek Geliştirme Çalışması: Yerli Sosyal Sermaye Ölçeği. İnsan ve Toplum Bilimleri Araştırmaları Dergisi, Vol. 9, No. 3, pp. 2039-2061.

Tatl1, H. (2013a). Yoksulluk ve Sosyal Sermaye: TRB1 Bölgesi’nde (Malatya, Elazı̆ğ, Bingöl, Tunceli) Bir Araştırma. Doktora Tezi.

(2013b). Sosyal Sermayenin Bireylerin İstihdamı Üzerindeki Etkisi Hanehalk1 Reisleri Üzerine Bir Araştırma. Gazi Üniversitesi İktisadi ve İdari Bilimler Fakültesi Dergisi, Cilt 15, Sayı 3, s. 87-114. 
Tocqueville, Alexis de (2002 [1835]). Democracy in America. Pen State Electronic Classics Series Publication.

Toprakç1-Alp, G. and, Aksoy, B. (2019). Women Entrepreneurship and Social Capital: A Qualitative Research. Mehmet Akif Ersoy Üniversitesi Sosyal Bilimler Enstitüsü Dergisi, Cilt 11, Sayı 27, s.126-148.

Türkseven, D.N. and Kutlar, A. (2019). TR71 Bölgesinin Bölgesel Geliri ve Sosyal Sermayesi Arasındaki İlişkinin Değerlendirilmesi. Niğde Ömer Halisdemir Üniversitesi Sosyal Bilimler Enstitüsü Dergisi, Kapadokya Sosyal Bilimler Öğrenci Kongresi Özel Sayısı, s. 12-21.

Uçar, E. (2016). Sosyal Sermaye Ölçeğinin Geçerlik ve Güvenirlik Çalışması. Ihlara Eğitim Araştırmaları Dergisi., Cilt 1, Sayı 1, s. 1-23.

US Congress Joint Economic Committee (2018). The Geography of Social Capital in America. SCP Report No. 1-18.

Van Beuningen, J. and Schmeets, H. (2013). Developing a Social Capital Index for the Netherlands. Social Indicators Research, Vol. 114, No. 3, pp. 859-886.

Van Staveren, I. (2002). Social Capital: What is in it for Feminist Economics. International Institute of Social Studies Working Papers - General Series 19126, The Hague: International Institute of Social Studies of Erasmus University Rotterdam.

Vergil, H. and Bahtiyar, B. (2017). Ekonomik Büyüme Farklılıklarının Açıklanmasında Sosyal Sermayenin Etkisi: Güven Düzeyi Üzerinden Karşılaştırmalı Bir Analiz. Uluslararası Yönetim İktisat ve İşletme Dergisi, ICMEB17 Özel Sayısı, s. 673-686.

Vosta, L.N. and Jalilvand, M.R. (2014). World Journal of Entrepreneurship, Management and Sustainable Development, Vol. 10, No. 3, pp. 209-227.

Warren, M.R., Thompson, P.J. and Saegert, S. (2001). The Role of Social Capital in Combating Poverty. In: Saegert, S., Thompson, P.J. and Warren, M.R. Social Capital and Poor Communities. New York: Russell Sage Foundation Press.

Weatherly, U.G. (1910). Race and Marriage. American Journal of Sociology, Vol. 15, No. 4, pp. 433453.

Weaver, R.D., McMurphy, S.M. \& Habibov, N.N. (2013). Analyzing the Impact of Bonding and Bridging Social Capital on Economic Well-Being: Results from Canada's General Social Survey. Sociological Spectrum, Vol. 33, No. 6, pp. 566-583. 
Wichowsky, A. (2019). Civic Life in the Divided Metropolis: Social Capital, Collective Action, and Residential Income Segregation. Urban Affairs Review, Vol. 55, No. 1, pp. 257-287.

William, D. (2006). On and Off the 'Net: Scales for Social Capital in an Online Era. Journal of Computer-Mediated Communication, Vol. 11, No. 2, pp. 593-628.

Woolcock, M. (1998). Social Capital and Economic Development: Toward a Theoretical Synthesis and Policy Framework. Theory and Society, Vol. 27, pp. 151-208.

(2000). The Place of Social Capital in Understanding Social and Economic Outcomes. Available at: https://www.oecd.org/innovation/research/1824913.pdf Accessed on: 20/04/2021.

Woolcock, M. and Narayan, D. (2000). Social Capital: Implications for Development Theory, Research, and Policy. The World Bank Research Observer, Vol. 15, No. 2, pp. 225-249.

World Bank (2000). World Development Report 2000/01. New York: Oxford University Press.

Xue, L. (2008). Social Capital and Employment Entry of Recent Immigrants to Canada: Evidence from the Longitudinal Survey of Immigrants to Canada. Citizenship and Immigration Canada. 